\begin{tabular}{|c|c|}
\hline 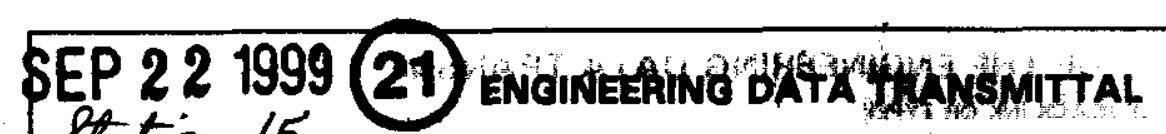 & 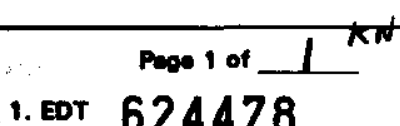 \\
\hline
\end{tabular}

\begin{tabular}{|c|c|}
\hline $\begin{array}{l}\text { 2. To: (Receiving Organization) } \\
\text { Distribution }\end{array}$ & $\begin{array}{l}\text { 3. From: (Orlginating Organization) } \\
\text { RRR Vadose Zone Project }\end{array}$ \\
\hline $\begin{array}{l}\text { 5. Proj./Prog./Dept./Div.: } \\
73500\end{array}$ & $\begin{array}{l}\text { 6. Design Authorty/Dosign Agent/Cog. Engt. } \\
\text { T. E. Jones. }\end{array}$ \\
\hline
\end{tabular}

\section{Originator Remenks:}

For Approval/Release

11. Recelver Remarks:

$$
\text { 11A. Design Baseline Document? } O \text { Yes } O \text { No }
$$

4. Related EDT No.:
N/A
7. Purchase Order No.:
N/A

9. Equip./Component No.:

$\mathrm{N} / \mathrm{A}$

10. Syctem/Bidg./Facility:

N $/ \mathrm{A}$

12. Major Aasm. Dwg. No.:

$\mathrm{N} / \mathrm{A}$

13. Permitrermit Application No.:

$\mathrm{N} \angle \mathrm{A}$

14. Required Response Date:

N/A

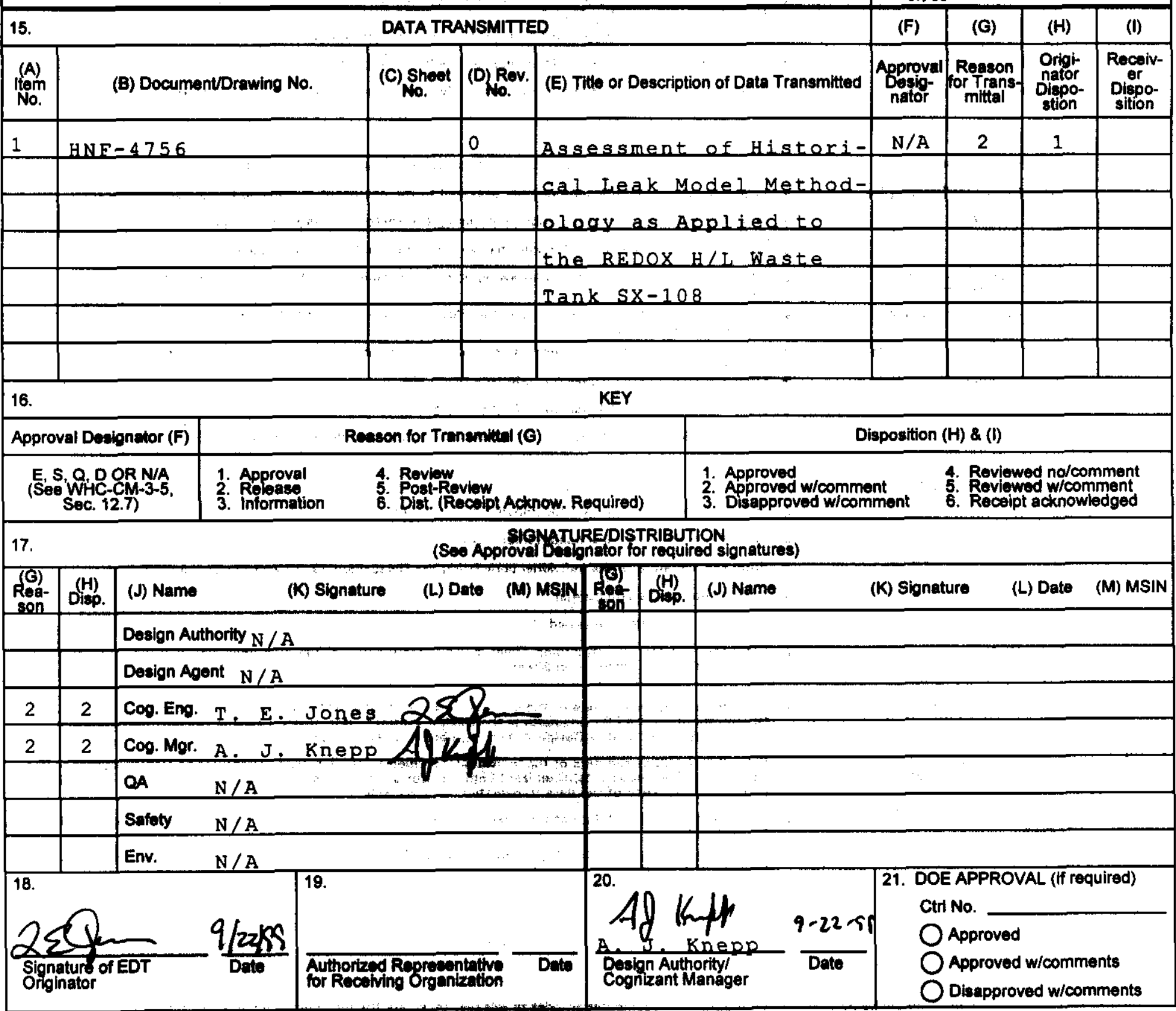




\title{
Assessment of Historical Leak Model Methodology as Applied to the REDOX High-Level Waste Tank SX-108
}

\author{
T. E. Jones, Ph.D. \\ Lockheed Martin Hanford Corporation \\ Richland, WA 99352 \\ U.S. Department of Energy Contract DE-AC06-96RL13200 \\ EDT/ECN: 624478 \\ Org Code: 73500 \\ B\&R Code: EW31200000 \\ UC: 2000 \\ Charge Code: 106503CA40 HN9 20601 \\ Total Pages:
}

Key Words: High-Level Waste Tank Leaks, REDOX Waste, Tank 241-SX-108, Historical Leak Model, Tank Heat Loads, Tank Heat Balance

Abstract: Using the Historical Leak Model approach, the estimated leak rate (and therefore, projected leak volume) for Tank 241-SX-108 could not be reproduced using the data included in the initial document describing the leak methodology. An analysis of parameters impacting tank heat load calculations strongly suggest that the historical tank operating data lack the precision and accuracy required to estimate tank leak volumes using the Historical Leak Model methodology.

TRADEMARK DISCLAMER. Reference herein to any specific commercial product, process, or service by trade name, trademark, manufacturer, or otherwise, does not necessarily constitute or imply its endorsement, recommendation, or fevoring by the United States Government or any agency thereof or its contractors or subcontractore.

Printed in the Uniled States of America. To obtain copies of this document, contact: Document Control Services, P.O. Box 950, Mailatop H6-08, Richland WA 99352, Phone (509) 372-2420; Fax (509) 376-4989.

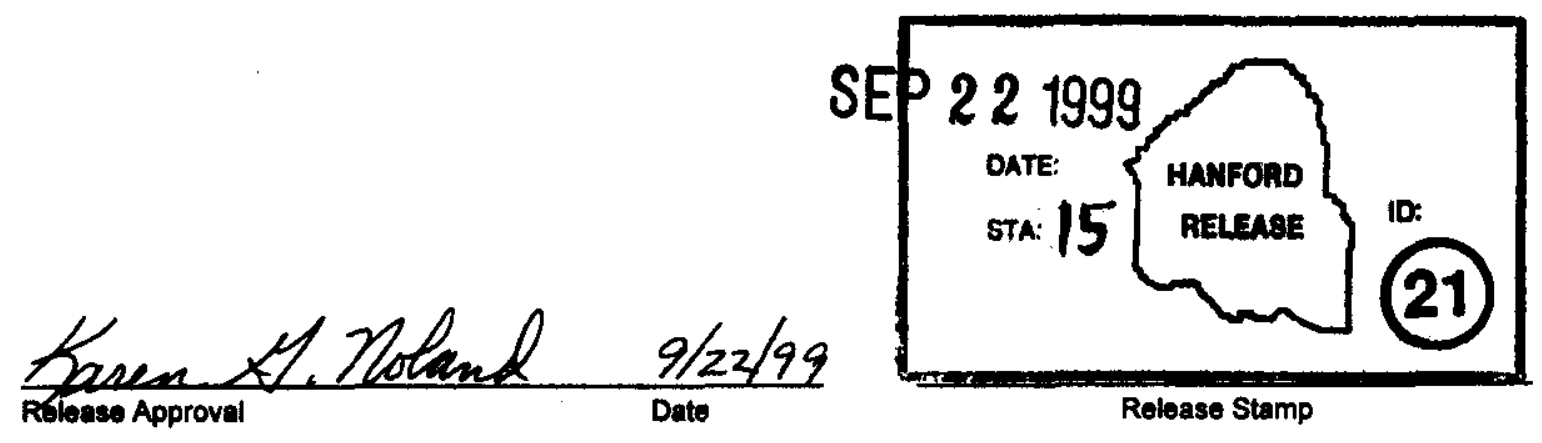

Approved For Public Release 


\section{Assessment of Historical Leak Model Methodology as Applied to the REDOX High-Level Waste Tank SX-108}

T. E. Jones, Ph.D.

Lockheed Martin Hanford Corporation

Date Published

July 1999

Prepared for the U.S. Department of Energy

wen basal mareos, we. 9

P.O. Box 1000

Richland, Washington

Honford Management and Integration Contractor for the U.S. Department of Energy under Contract DE-AC06-96RL13200 


\section{CONTENTS}

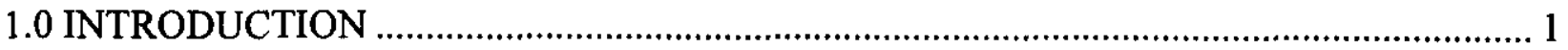

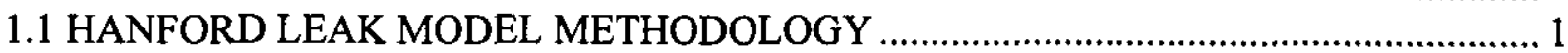

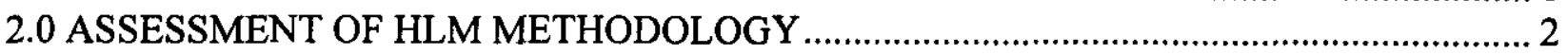

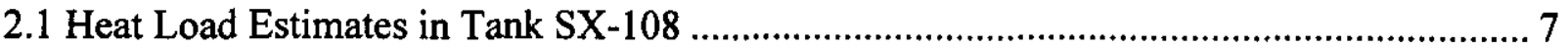

2.2 Uncertainties in Heat Losses to Soil and Air................................................................ 7

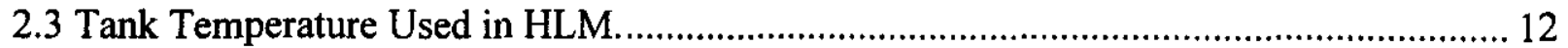

2.4 Uncertainties in Latent Heats of Vaporization.............................................................. 14

2.5 Material Balance During Quiescent Period .................................................................. 14

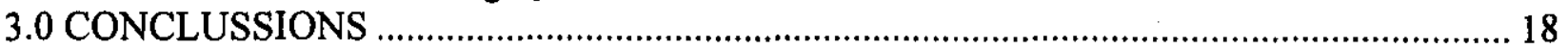

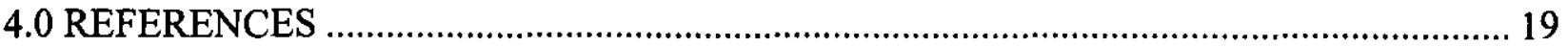

\section{APPENDIX}

A Evaluation of Historical Leak Model for Tank SX-108 Decay Power

\section{LIST OF FIGURES}

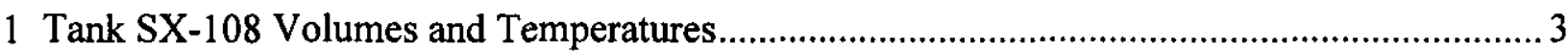

2 Tank SX-108 Unaccounted for Gain or Loss, Evaporation, and Leak Rates ............................. 4

3 Tank SX-108 Decay Power Profile..................................................................................... 8

4 Tank SX-108 Head Loads and Tank Temperatures................................................................ 10

5 Temperatures Around an Underground Waste Storage Tank

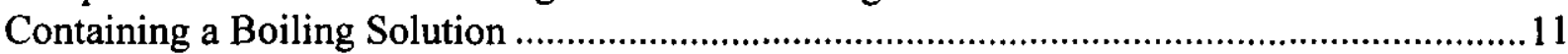

6 Tank SX-108 Heat Load and Percent Heat Lost to Air and Soil ...........................................13

7 Calculated and Measured Waste Volumes in Tank SX-108 ..................................................16

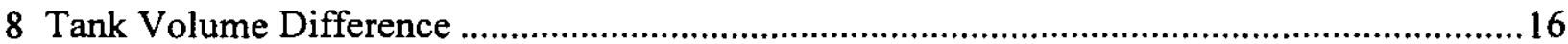

\section{LIST OF TABLES}

1 Tank SX-108 Tank Volume Data and Calculated Heat Loads .................................................. 5

2 Estimated Heat Losses and Evaporative Cooling Volume Losses .............................................. 6

3 Calculated Volume Losses................................................................................................. 9 
HNF-4756, Rev. 0

\section{ASSESSMENT OF HISTORICAL LEAK MODEL METHODOLOGY AS APPLIED TO THE REDOX HIGH-LEVEL WASTE TANK SX-108}

\subsection{INTRODUCTION}

In 1996, S. F. Agnew and co-workers (Agnew and Corbin 1998) developed the historical leak model (HLM), an approach for estimating leak volumes in high-heat tanks at the Hanford Site. Their approach uses heat loads in the tank, estimated tank volume decreases based on evaporative cooling requirements, and measured waste volumes in the tank to estimate how much waste the tank may have lost through leakage. This methodology was applied to four reduction-oxidation (REDOX) process high-level waste (HLW) tanks (SX-108, -109, -111, and 112 ) in the SX tank farm that are known to have leaked (Hanlon 1999). The leak volumes estimated using the HLM were considerably higher than those routinely reported in the monthly Hanford Site tank farms status report (Hanlon 1999). These differences generated considerable interest in the methodology and its potential applicability to other high-heat tanks at the Hanford Site. If the methodology is sound, the U.S. Department of Energy (DOE) has committed to apply the HLM to all appropriate tanks.

The Lockheed Martin Hanford Corporation (LMHC) Tank Farm Vadose Zone Program is currently using Agnew's Hanford Defined Waste (HDW) Model (Kupfer et al. 1998) to estimate tank compositions at the time of suspected leaks in 24 single-shell tanks (SST). DOE staff has suggested that, for all appropriate tanks, LMHC consider using the HLM methodology to estimate leak volumes concurrently with leak composition. This assessment of the HLM methodology was undertaken to better formulate LMHC's response to the DOE staff request.

\subsection{HANFORD LEAK MODEL METHODOLOGY}

Fuel production in the Hanford Site reactors and subsequent plutonium-recovery processing are well documented. Thus, existing computer codes, such as OREGIN2 and the HDW model, can be used to estimate the radionuclide inventory in any Hanford Site HLW tank at any point in time. Using these computer codes we can feasibly quantify the heat load generated from radioactive decay in any high-heat tank as a function of time. A known volume of water was added to the tanks each month to facilitate dissipating a significant quantity of the heat load through evaporative cooling. The volume of water lost each month through evaporative cooling can be estimated using the heat load and latent heat of vaporization for water. The basis of the HLM model is comparing the estimated volume decrease caused by evaporation and documented tank volume measurements. If the volume losses over a specific period were greater than the volume estimated to have been lost through evaporation, the excess volume lost was ascribed to a tank leak. Tank waste volumes were corrected to account for the frequent additions of liquids to the tank.

When the heat load in a tank was high, a large quantity of water was evaporated and replaced monthly, making volume losses caused by leaks difficult to detect. Thus, the HLM methodology is applicable only to the limited period when the heat load had dropped significantly and transfers into the tank were minimal (Agnew and Corbin 1998). This was referred to as a 
"quiescent period". To develop a maximum credible leak volume, when tank leaks were identified during a quiescent period, the leak was assumed to have been active during the nonquiescent periods as well. For example, an estimated leak volume of approximately $11 \mathrm{~kL} /$ month ( $3 \mathrm{kgal} /$ month) determined from July 1959 through April 1962 in tank SX-108 using the HLM was applied from mid-1959 through February 1967 (Agnew and Corbin 1998) to estimate a leak volume near $757 \mathrm{~kL}$ (200 kgal). The only adjustment in the monthly leak rate was to factor in the hydraulic head in the tank based on waste volume.

Because of its embedded assumptions, the HLM methodology includes several areas where potentially large uncertainties can be introduced into the calculations. Obviously, the quality of the radionuclide inventory estimate in a specific tank depends on the accuracy of both the OREGIN2 calculations and the waste transfer records. Heat losses from mechanisms other than evaporative cooling also complicate the water loss analysis. The historical tank level measurements are, of course, critical to HLM methodology. This assessment evaluates the potential impacts of different values for various imbedded assumptions on the postulated leak volume from tank SX-108 and recalculates tank waste material balances from 1959 through mid1962 , a quiescent period in this tank.

\subsection{ASSESSMENT OF HLM METHODOLOGY}

The data from January 1959 through April 1962 for tank SX-108 were chosen for this assessment because Agnew and Corbin (1998) identified this as a quiescent period where his analysis indicated the beginning of a tank leak event, as shown in Figures 1 and 2. In addition, D. Wootan of Fluor Daniel Northwest (FDNW) repeated the heat load calculations for tank SX-108 as an over-check of that aspect of the HLM methodology (see Appendix A).

Table 1 shows the data available for ascertaining the presence of a tank leak in tank SX-108 during the time period of interest. These include measured tank waste volumes reported monthly from January 1959 through October 1960 and biannually over the remaining period, volumes of liquid added to the tank, and two sets of tank heat load estimates. The only other data required to estimate expected tank waste volumes are estimates of heat loss to the soil and air. These estimates were developed by Agnew and Corbin (1998) and are provided in Table 2. This data set is sufficient to estimate expected tank waste volumes and, thus, identify potential tank leaks by comparing calculated tank waste volumes with measured volumes.

This assessment includes a sensitivity analysis of the impact of recalculated heat loads on volume decreases in tank SX-108 caused by evaporative cooling over the time period of interest, heat losses to the soil and air, uncertainties in thermodynamic data used to calculate volume decreases, and material balance in the tank over this period. 
Figure 1. Tank SX-108 Volumes and Temperatures (Agnew and Corbin 1998).

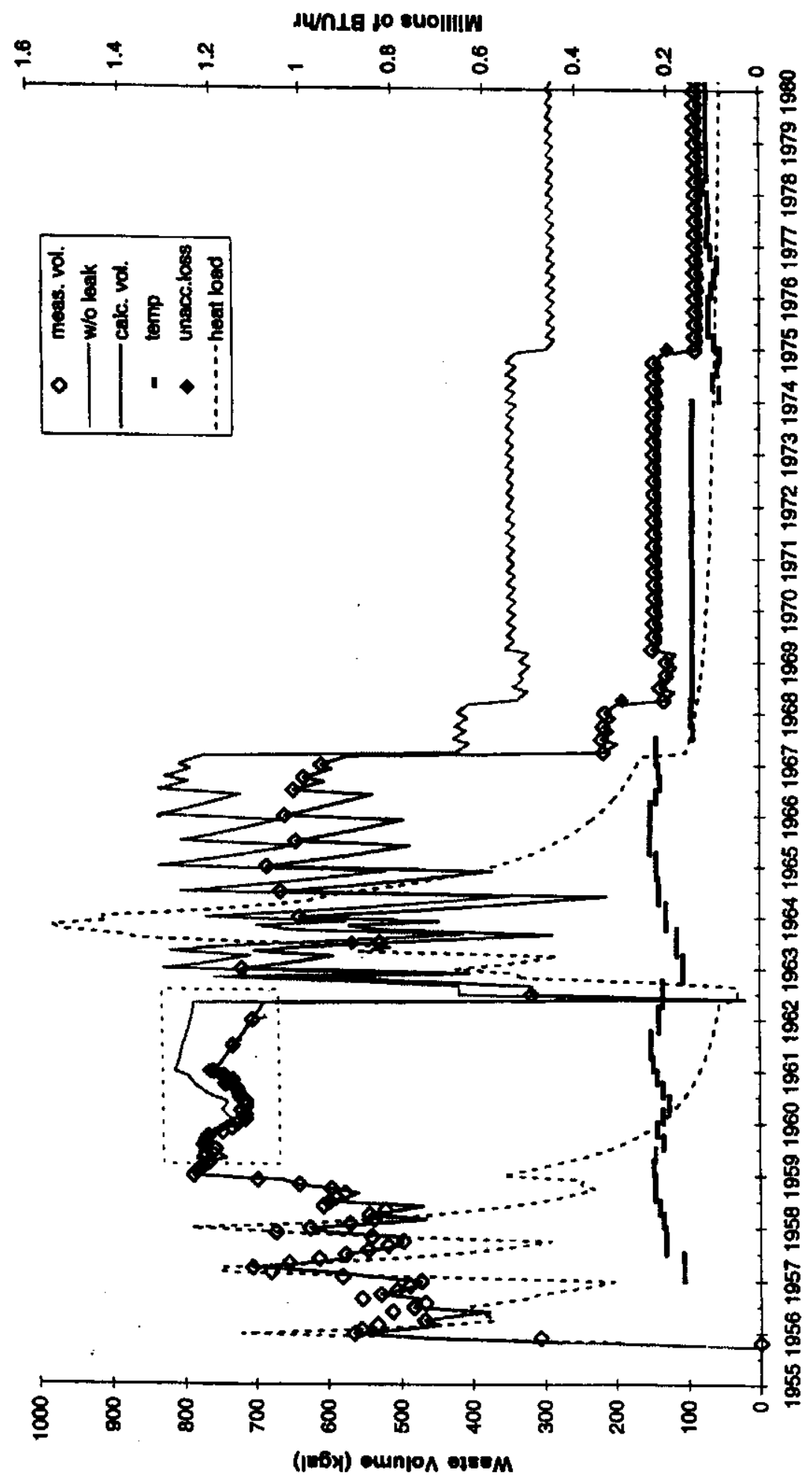


Figure 2. Tank SX-108 Unaccounted for Gain or Loss, Evaporation, and Leak Rates (Agnew and Corbin 1998).

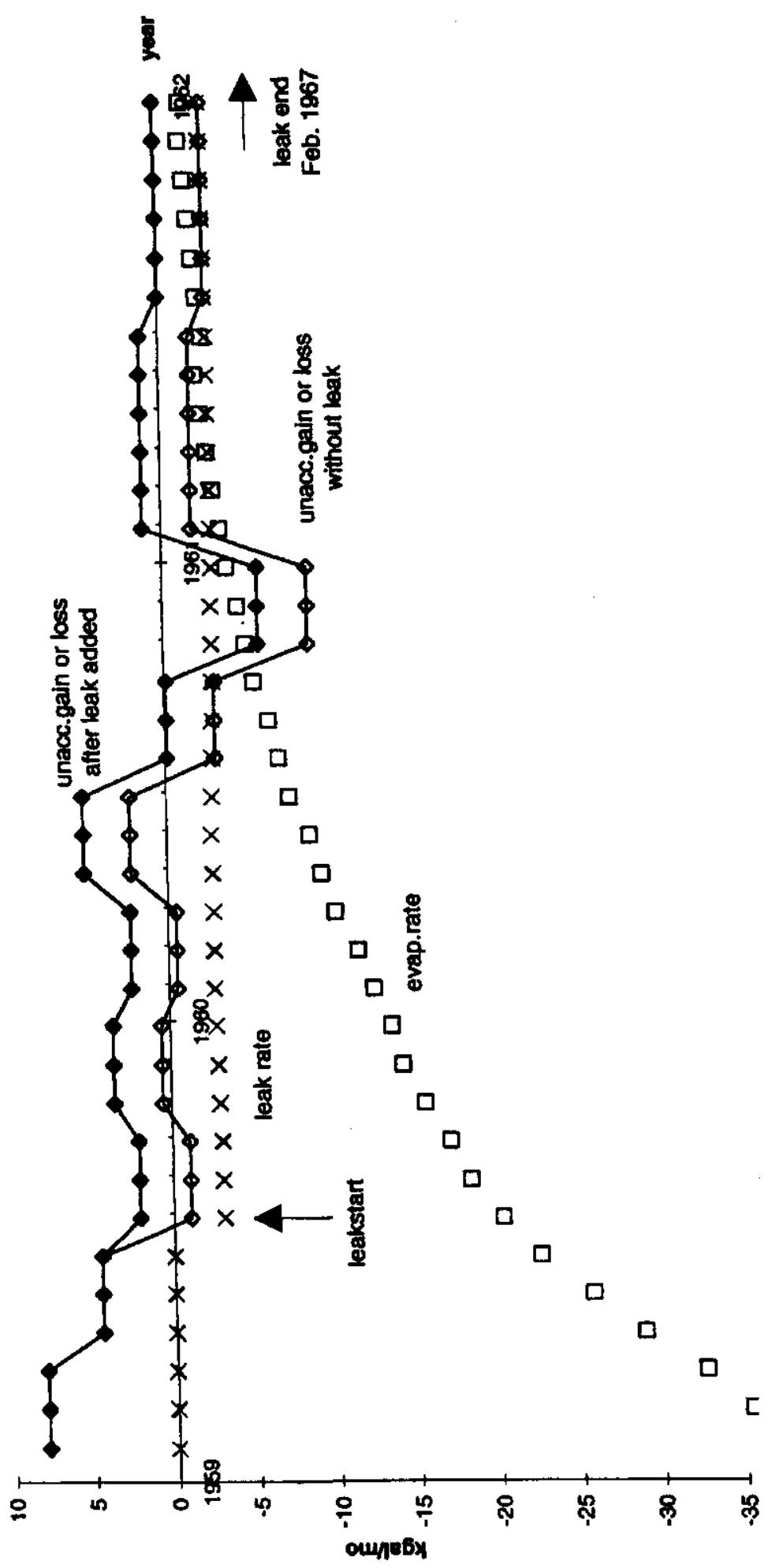


Table 1. Tank SX-108 Tank Volume Data and Calculated Heat Loads.

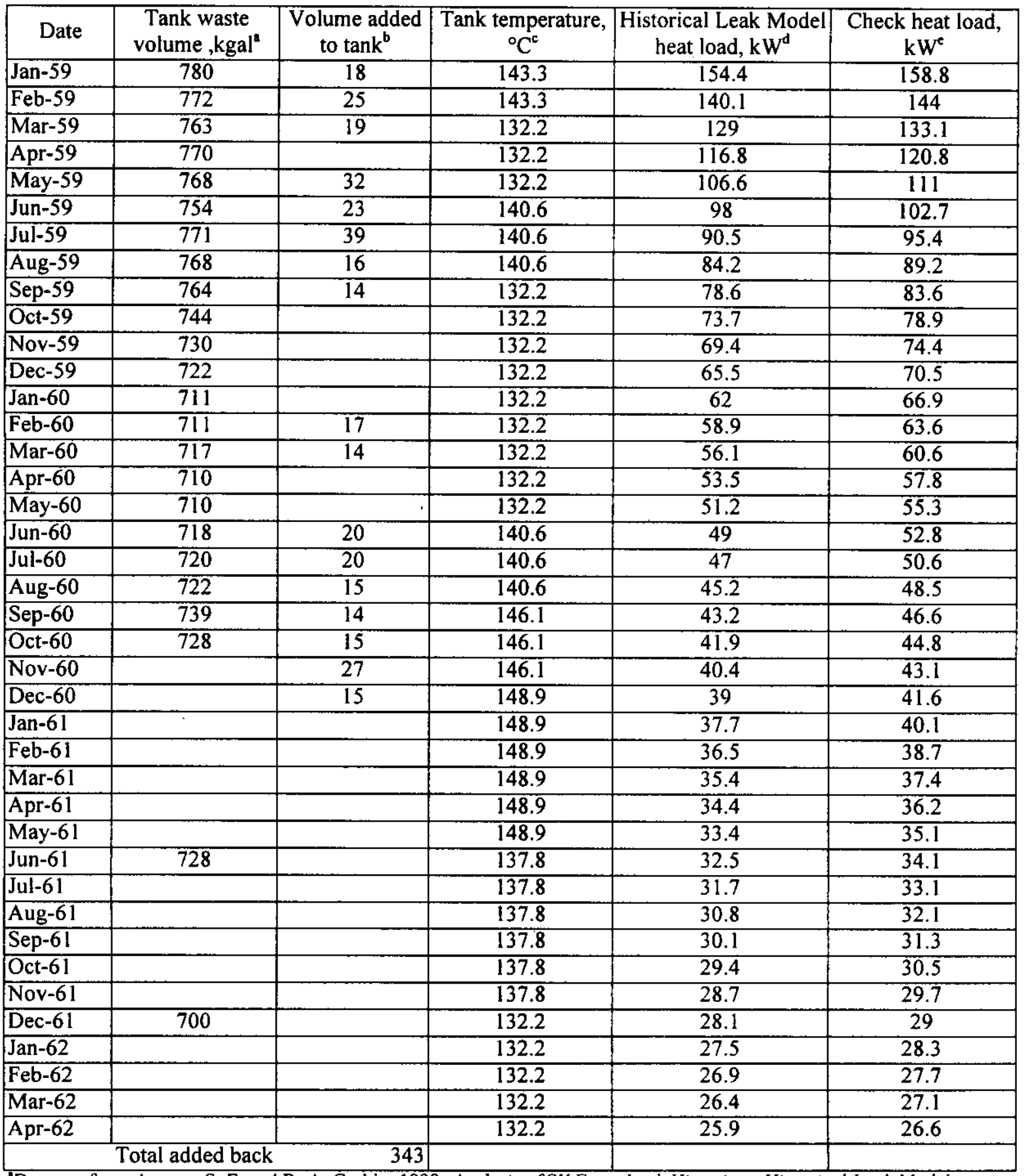

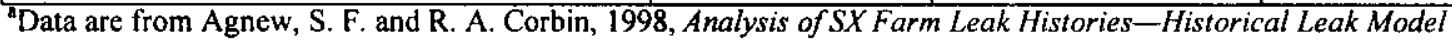
(HLM), Los Alamos National Laboratory, Los Alamos, New Mexico.

${ }^{b}$ Volume of liquids added back to tank are from Agnew and Corbin (1998) and Agnew, S. F., 1995, Waste Status and Transaction Record Summary (WSTRS Rev.2), WHC-SD-WM-TI-615, -614, 669, -689, Rev. 2., prepared by Los Alamos National Laboratory, Los Alamos, New Mexico, for Westinghouse Hanford Company, Richland, Washington.

${ }^{c}$ Tank waste temperatures are from Agnew (1998)

${ }^{d} \mathrm{HLM}$ heat loads are from Agnew (1998)

${ }^{\circ}$ Check heat loads are from Wooten, D. W., 1998, Evaluation of Historical Leak Model for Tank SX-108 Decay Power, Fluor Daniel Northwest, Inc., Richland, Washington, delivered under Fluor Daniel Northwest, Inc., correspondence number FDNW-RJP-98-025 
Table 2. Estimated Heat Losses and Evaporative Cooling Volume Losses.

\begin{tabular}{|c|c|c|c|c|c|c|}
\hline Date & $\begin{array}{l}\text { HLM heat } \\
\text { load, } \mathrm{kW}^{\mathrm{a}}\end{array}$ & $\begin{array}{l}\text { Heat lost to } \\
\text { ground, } \mathrm{kW}^{\mathrm{a}}\end{array}$ & $\begin{array}{l}\text { Heat lost to } \\
\text { air, } \mathrm{kW}^{\mathrm{a}}\end{array}$ & $\begin{array}{l}\% \text { heat lost to } \\
\text { ground and air }\end{array}$ & $\begin{array}{c}\text { HLM heat to } \\
\text { vaporization, } \mathrm{kW}\end{array}$ & $\begin{array}{l}\text { HLM Volume } \\
\text { Evaporated, } \text { kgal }^{\mathrm{c}}\end{array}$ \\
\hline \begin{tabular}{|l}
$\operatorname{Jan} 59$ \\
\end{tabular} & 154.4 & 12.5 & 12.4 & 16.13 & 129.5 & 39.75 \\
\hline Feb 59 & 140.1 & 12.5 & 12.4 & 17.77 & 115.2 & 35.36 \\
\hline Mar 59 & 129 & 11.4 & 11.3 & 17.60 & 106.3 & 32.63 \\
\hline$\overline{\mid A p r 59}$ & 116.8 & 11.4 & 11.3 & 19.43 & 94.1 & 28.88 \\
\hline May 59 & 106.6 & 11.4 & 11.3 & 21.29 & 83.9 & 25.75 \\
\hline Jun 59 & 98 & 12.3 & 12.2 & 25.00 & 73.5 & 22.56 \\
\hline Jul 59 & 90.5 & 12.3 & 12.2 & 27.07 & 66 & 20.26 \\
\hline \begin{tabular}{|l} 
Aug 59 \\
\end{tabular} & 84.2 & 12.3 & 12.2 & 29.10 & 59.7 & 18.32 \\
\hline Sep 59 & 78.6 & 11.4 & 11.3 & 28.88 & 55.9 & 17.16 \\
\hline Oct 59 & 73.7 & 11.4 & 11.3 & 30.80 & 51 & 15.65 \\
\hline Nov 59 & 69.4 & 11.4 & 11.3 & 32.71 & 46.7 & 14.33 \\
\hline Dec 59 & 65.5 & 10.6 & 10.5 & 32.21 & 44.4 & 13.63 \\
\hline $\operatorname{Jan} 60$ & 62 & 10.6 & 10.5 & 34.03 & 40.9 & 12.55 \\
\hline Feb 60 & 58.9 & 10.6 & 10.5 & 35.82 & 37.8 & 11.60 \\
\hline Mar 60 & 56.1 & 11.4 & 11.3 & 40.46 & 33.4 & 10.25 \\
\hline Apr 60 & 53.5 & 11.4 & 11.3 & 42.43 & 30.8 & 9.45 \\
\hline May 60 & 51.2 & 11.42 & 11.3 & 44.38 & 28.48 & 8.74 \\
\hline Jun 60 & 49 & 12.3 & 12.2 & 50.00 & 24.5 & 7.52 \\
\hline Jul 60 & 47 & 12.3 & 12.2 & 52.13 & 22.5 & 6.91 \\
\hline Aug 60 & 45.2 & 12.3 & 12.2 & 54.20 & 20.7 & 6.35 \\
\hline Sep 60 & 43.2 & 12.8 & 12.7 & 59.03 & 17.7 & 5.43 \\
\hline Oct 60 & 41.9 & 12.8 & 12.7 & 60.86 & 16.4 & 5.03 \\
\hline Nov 60 & 40.4 & 12.8 & 12.7 & 63.12 & 14.9 & 4.57 \\
\hline Dec 60 & 39 & 13.1 & 13 & 66.92 & 12.9 & 3.96 \\
\hline $\operatorname{Jan} 61$ & 37.7 & 13.1 & 13 & 69.23 & 11.6 & 3.56 \\
\hline Feb 61 & 36.5 & 13.1 & 13 & 71.51 & 10.4 & 3.19 \\
\hline Mar 61 & 35.4 & 13.1 & 13 & 73.73 & 9.3 & 2.85 \\
\hline Apr 61 & 34.4 & 13.1 & 13 & 75.87 & 8.3 & 2.55 \\
\hline May 61 & 33.4 & 13.1 & 13 & 78.14 & 7.3 & 2.24 \\
\hline Jun-61 & 32.5 & 12 & 11.9 & 73.54 & 8.6 & 2.64 \\
\hline Jul-61 & 31.7 & 12 & 11.9 & 75.39 & 7.8 & 2.39 \\
\hline Aug 61 & 30.8 & 12 & 11.9 & 77.60 & 6.9 & 2.12 \\
\hline Sep 61 & 30.1 & 12 & 11.9 & 79.40 & 6.2 & 1.90 \\
\hline Oct 61 & 29.4 & 12 & 11.9 & 81.29 & 5.5 & 1.69 \\
\hline Nov 61 & 28.7 & 12 & 11.9 & 83.28 & 4.8 & 1.47 \\
\hline Dec 61 & 28.1 & 11.4 & 11.3 & 80.78 & 5.4 & 1.66 \\
\hline \begin{tabular}{|l}
$\operatorname{Jan} 62$ \\
\end{tabular} & 27.5 & 11.4 & 11.3 & 82.55 & 4.8 & 1.47 \\
\hline Feb 62 & 26.9 & 11.4 & 11.3 & 84.39 & 4.2 & 1.29 \\
\hline Mar 62 & 26.4 & $\Pi 1.4$ & 11.3 & 85.98 & 3.7 & 1.14 \\
\hline Apr 62 & 25.9 & 11.4 & 11.3 & 87.64 & 3.2 & 0.98 \\
\hline & & & \multicolumn{3}{|c|}{ Total lost through December 61} & 404.9 \\
\hline
\end{tabular}

${ }^{2}$ Data are from Agnew, S. F. and R. A. Corbin, 1998, Analysis of SX Farm Leak Histories-Historical Leak Model (HLM), Los Alamos National Laboratory, Los Alamos, New Mexico.

$b_{\%}$ heat loss $=$ Heat loss to ground + heat loss to air $\times 100$

$$
\text { HLM Heat Load }
$$

${ }^{\circ} \mathrm{C}$ alculated here and listed in Agnew and Corbin (1998) 


\subsection{HEAT LOAD ESTIMATES IN TANK SX-108}

D. A. Wootan, FDNW, recalculated the decay power by month in tank SX-108 between 1955 and 1968 using the OREGIN2 computer code (see Appendix A) For consistency, the recalculation used the same fuel batch processing and waste transfer records as Agnew's calculations (Agnew and Corbin 1998). The differences between the check values and the HLM values ranged from -4 percent to +9 percent, except for one batch of low-exposure fuel. The greater differences were noted during the high-heat time periods. This comparison is shown in Figure 3. The integrated decay power over the entire time period was 3 percent greater in the check power profile than in the HLM power profile. The conclusion was that the two data sets were consistent within the uncertainties associated with the necessary assumptions.

Table 1 lists the heat loads by month (i.e., decay power) for January 1959 through April 1962 from both the HLM and check calculations. Figure 4 shows the same data graphically. Using these data, values for water lost to evaporative cooling can be compared for HLM heat load(column 7, Table 2) and check heat load (column 4 Table 3) calculations. The evaporative cooling losses were calculated using the other assumptions imbedded in the HLM methodology. That is, assuming heat losses to the soil and air reported in Agnew and Corbin (1998) and using Agnew's thermodynamic assumptions.

For the January 1959 to September 1960 period, the check heat load values calculated by Wootan resulted in an estimate of approximately $492 \mathrm{~L}(1.3 \mathrm{kgal})$ more per month lost to evaporative cooling than the estimate using the HLM heat values. This is not an attempt to suggest that one set of numbers are more correct than the other, but to show the impacts of minor differences in heat load on estimated volume losses to evaporative cooling. Because the HLM methodology identifies an approximately $11 \mathrm{~kL}$ ( $3 \mathrm{kgal})$ per month leak rate in SX-108 beginning in July 1959 (Agnew and Corbin 1998), a $492 \mathrm{~L}$ (1.3 kgal) change indicates a relatively large uncertainty in the monthly leak rate.

However, as shown in Figure 3 and 4, the two heat load data sets contain only minor differences. The consistent minor difference does not account for the shift in the difference between evaporative cooling losses and tank levels noted by Agnew and Corbin (1998) for July 1959, and identified as the beginning of the tank leak (see Figures 1 and 2).

\subsection{UNCERTAINTIES IN HEAT LOSSES TO SOIL AND AIR.}

The transfer of heat from high-heat tanks on the Hanford Site to the soils has been evaluated extensively (Jansen 1964, Jansen et al. 1966, and Willingham and Jansen 1966). The largest uncertainty associated with heat transfer from tanks to the soil is caused by the lack of data on the moisture content of soils around the tanks (Jansen et al. 1966). There is a factor of fourfold difference in thermal conductivity between dry and wet Hanford Site soils (Jansen et al.1966). Under the conditions of a well-mixed boiling waste tank, $15,800 \mathrm{btu} / \mathrm{hr}(4.6 \mathrm{~kW})$ would be lost through dry soils and $63,900 \mathrm{btu} / \mathrm{hr}(18.7 \mathrm{~kW})$ would be lost through wet soil, with over 80 percent of the heat being lost to the ground surface. According to Jansen et al. (1966), complex temperature profiles would develop in the soils around the tank (see Figure 5). 
Figure 3. Tank SX-108 Decay Power Profile (from Appendix A).

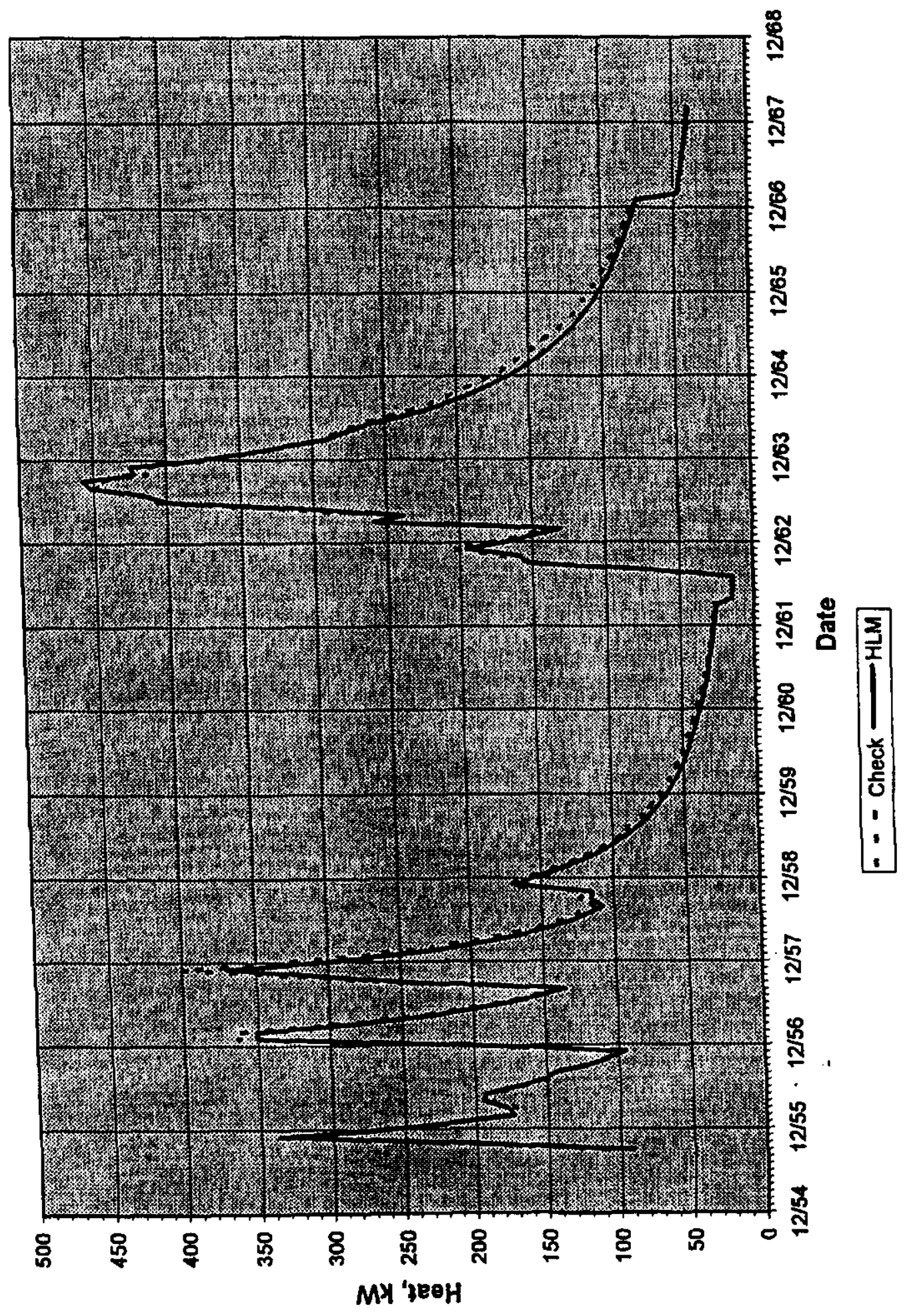


Table 3. Calculated Volume Losses.

\begin{tabular}{|c|c|c|c|c|c|c|c|c|}
\hline Date & $\begin{array}{c}\text { Measured } \\
\text { Tank } \\
\text { Volume } \\
\text { kgal }\end{array}$ & $\begin{array}{l}\text { Chk Heat to } \\
\text { Vapor., kW }\end{array}$ & $\begin{array}{c}\text { Chk-Volume } \\
\text { Evaporated } \\
\text { kgal }\end{array}$ & $\begin{array}{c}\text { Volume } \\
\text { added } \\
\text { to tank, } \\
\text { kgal }\end{array}$ & $\begin{array}{l}\text { HLM-heat } \\
\text { calc. tank } \\
\text { volume }\end{array}$ & $\begin{array}{c}\text { Chk-heat } \\
\text { calc. tank } \\
\text { volume }\end{array}$ & $\begin{array}{c}\text { HLM } \\
\text { Tank Vol } \\
\text { Differ. }\end{array}$ & $\begin{array}{c}\text { Chk } \\
\text { Tank Vol } \\
\text { Differ. }\end{array}$ \\
\hline $\operatorname{Jan} 59$ & 780 & 133.9 & 41.10 & 18 & 758.25 & 756.90 & 13.75 & 15.10 \\
\hline Feb $5 \overline{9}$ & 772 & 119.1 & 36.55 & 25 & 761.64 & 760.45 & 1.36 & 2.55 \\
\hline Mar 59 & 763 & 110.4 & 33.88 & 19 & 749.37 & 748.12 & 20.63 & 21.88 \\
\hline Apr 59 & 770 & 98.1 & 30.11 & & 741.12 & 739.89 & 26.88 & 28.11 \\
\hline May 59 & 768 & 88.3 & 27.10 & 32 & 774.25 & 772.90 & -20.25 & -18.90 \\
\hline Jun 59 & 754 & 78.2 & 24.00 & 23 & 754.44 & 753.00 & 16.56 & 18.00 \\
\hline Jul 59 & 771 & 70.9 & 21.76 & 39 & 789.74 & 788.24 & -21.74 & -20.24 \\
\hline Aug 59 & 768 & 64.7 & 19.86 & 16 & 765.68 & 764.14 & -1.68 & -0.14 \\
\hline Sep 59 & 764 & 60.9 & 18.69 & 14 & 760.84 & 759.31 & -16.84 & -15.31 \\
\hline Oct 59 & 744 & 56.2 & 17.25 & & 728.35 & 726.75 & 1.65 & 3.25 \\
\hline Nov 59 & 730 & 51.7 & 15.87 & & 715.67 & 714.13 & 6.33 & 7.87 \\
\hline Dec 59 & 722 & 49.4 & 15.16 & & 708.37 & 706.84 & 2.63 & 4.16 \\
\hline $\operatorname{Jan} 60$ & 711 & 45.8 & 14.06 & & 698.45 & 696.94 & 12.55 & 14.06 \\
\hline Feb 60 & 711 & 42.5 & 13.04 & 17 & 716.40 & 714.96 & 0.60 & 2.04 \\
\hline Mar 60 & 717 & 37.9 & 11.63 & 14 & 720.75 & 719.37 & -10.75 & -9.37 \\
\hline Apr 60 & 710 & 35.1 & 10.77 & & 700.55 & $699 . \overline{23}$ & 9.45 & 10.77 \\
\hline May 60 & 710 & 32.58 & 10.00 & & 701.26 & 700.00 & 16.74 & 18.00 \\
\hline Jun 60 & 718 & 28.3 & 8.69 & 20 & 730.48 & 729.31 & -10.48 & -9.31 \\
\hline Jul 60 & 720 & 26.1 & 8.01 & 20 & 733.09 & 731.99 & -11.09 & -9.99 \\
\hline Aug 60 & 722 & 24 & 7.37 & 15 & 730.65 & 729.63 & 8.4 & 9.37 \\
\hline Sep 60 & 739 & 21.1 & 6.48 & 14 & 747.57 & 746.52 & -19.6 & -18.52 \\
\hline Oct 60 & 728 & 19.3 & 5.92 & 15 & 737.97 & 737.08 & & \\
\hline Nov 60 & & 17.6 & 5.40 & 27 & & & & \\
\hline Dec 60 & & 15.5 & 4.76 & 15 & & & & \\
\hline $\operatorname{Jan} 61$ & & 14 & 4.30 & & & & Ave $=1.2$ & Ave $=2.5$ \\
\hline Feb 61 & & 12.6 & 3.87 & & & & S.D. $=14.4$ & S.D. $=14.4$ \\
\hline Mar 61 & & 11.3 & 3.47 & & & & & \\
\hline Apr 61 & & 10.1 & 3.10 & & & & & \\
\hline May 61 & & 9 & 2.76 & & & & & \\
\hline Jun 61 & 728 & 10.2 & 3.13 & & & & & \\
\hline Jul 61 & & 9.2 & 2.82 & & & & & \\
\hline Aug 61 & & 8.2 & 2.52 & & & & & \\
\hline Sep 61 & & 7.4 & 2.27 & & & & & \\
\hline Oct 61 & & 6.6 & 2.03 & & & & & \\
\hline Nov 61 & & 5.8 & 1.78 & & & & & \\
\hline Dec 61 & 700 & 6.3 & 1.93 & & & & & \\
\hline $\operatorname{Jan} 62$ & & 5.6 & 1.72 & & & & & \\
\hline Feb 62 & & 5 & 1.53 & & & & & \\
\hline Mar 62 & & 4.4 & 1.35 & & & & & \\
\hline Apr-62 & & 3.9 & 1.20 & & & & & \\
\hline \multicolumn{9}{|c|}{ Total added back $=343 \mathrm{kgal}$} \\
\hline & Total los & $t$ thru $12 / 61=$ & $441.4 \mathrm{kgal}$ & & & & & \\
\hline
\end{tabular}


Figure 4. Tank SX-108 Heat Loads and Tank Temperatures.

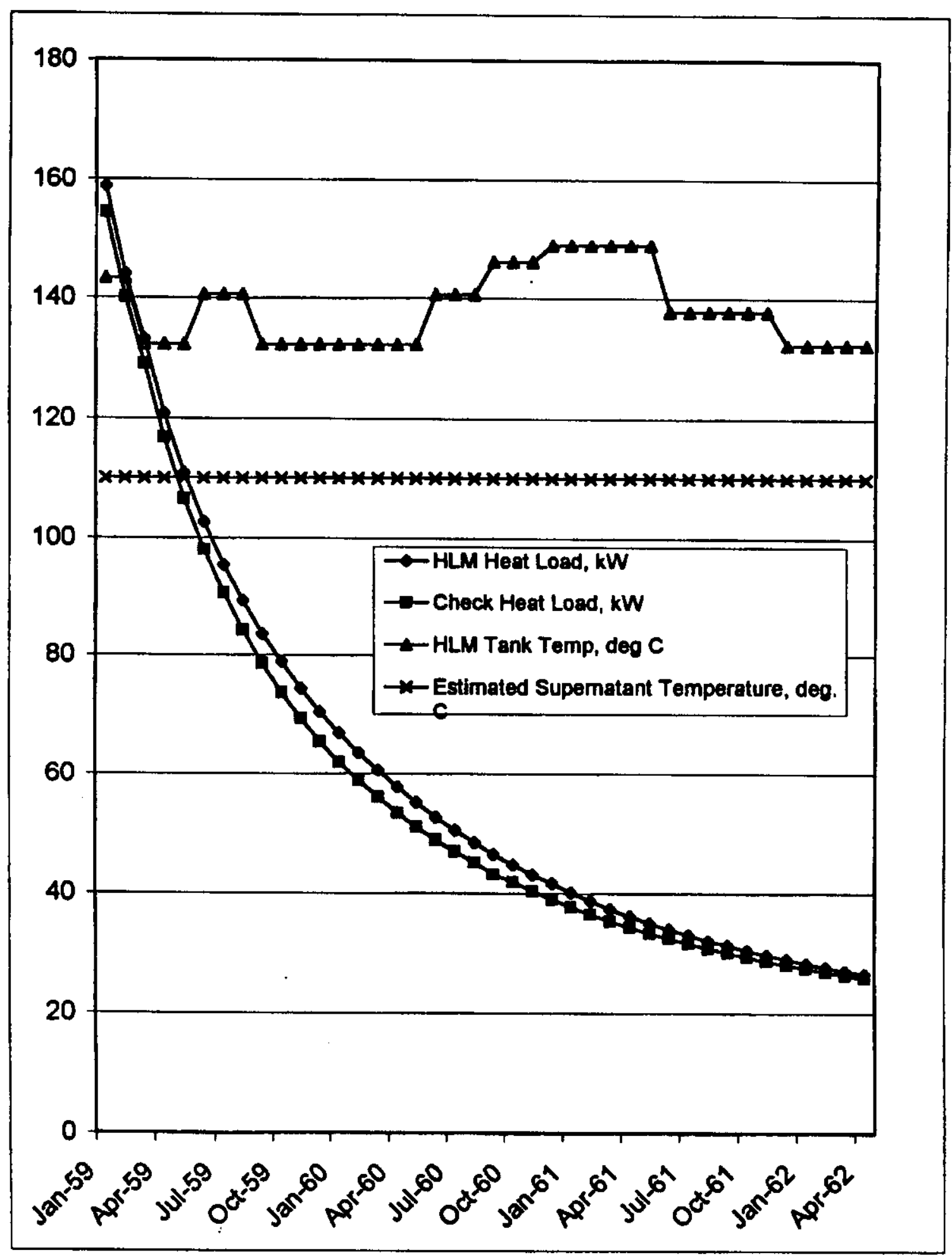


Figure 5. Temperatures Around an Underground Waste Storage Tank Containing a Boiling Solution (Dry Soil) (Jansen 1966).

$$
\mathrm{K}=0.15 \mathrm{btu} /(\mathrm{hr})\left(\mathrm{ft}^{2}\right)\left({ }^{\circ} \mathrm{F} / \mathrm{ft}\right)
$$

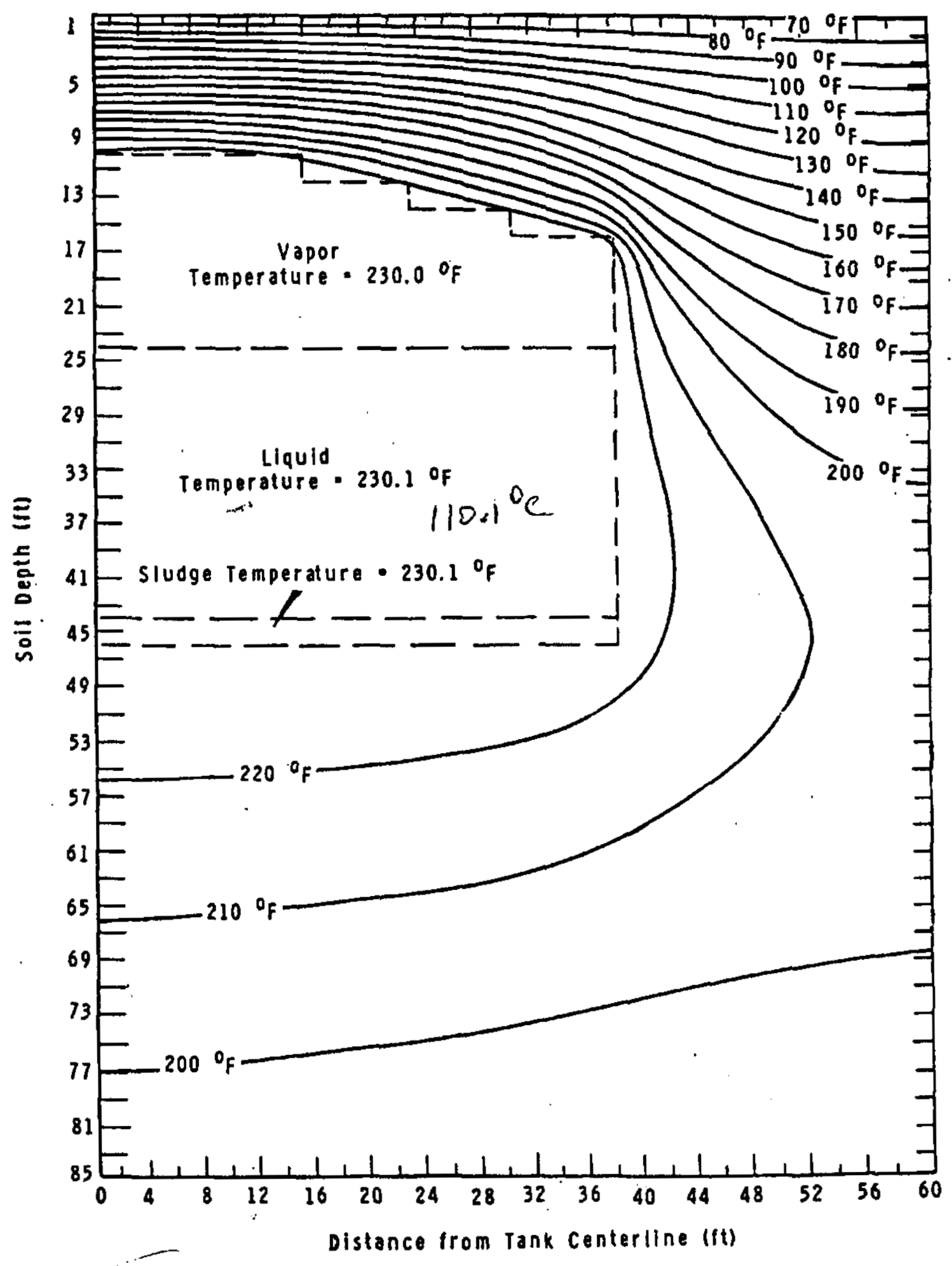


The HLM appears to treat heat losses to the soil simplistically when compared to the "textbook approach" for estimating heat loss from large tanks (Metcalf and Eddy 1991). The estimated heat transfer to the soil in the HLM appears to be calculated from the difference between the (assumed) temperature in the tank (approximately $140^{\circ} \mathrm{C}$ ) and a hypothetical soil temperature $\left(18^{\circ} \mathrm{C}\right)$ multiplied by an undefined constant. According to discussions with Agnew, the undefined constant was developed by fitting data from non-leaking high-heat tanks and included heat lost to both soil and air. The heat loss was scaled to be approximately $68,242 \mathrm{btu} / \mathrm{hr}$ $(20 \mathrm{~kW})$, apparently a design or operating parameter for the REDOX boiling waste tanks. [ref. Agnew 1999, private communication]

Quantifying heat lost to the air moving through the tank (the HLM lists the air flow as $2.83 \mathrm{~m}^{3} / \mathrm{min}\left[100 \mathrm{ft}^{3} / \mathrm{min}\right.$ ] during the time period of interest) is more complicated than addressing heat loss to the soil because the air duct systems were complicated. The air flow in the REDOX boiling waste tanks in the SX tank farm passed through multiple tanks sequentially to a central condenser, making any assessment difficult. No direct estimates of heat losses through the air in tank SX-108 are known. However, an assessment of the vapor losses from tank SX-109 developed to support another tank leak volume estimate defines some of the difficulties and missing information that must be addressed (Lewis 1987). Thus, empirically scaling heat loss from a similar, but non-leaking, tank, as Agnew did, may be one of the few realistic alternatives for addressing heat losses to the soil and air. The uncertainty associated with this estimate is unknown.

During the periods of maximum heat load in tank SX-108, the heat lost to the air and soil, as calculated by the HLM model, represents less that 20 percent of the total heat loss (Agnew and Corbin 1998). During these periods, uncertainties in the estimate of heat loss to the soil and air may be less consequential in a tank leak estimate. However, as the heat loads in the tank decrease, the percentage of the total heat load being lost to the soil and air increases significantly. The percent of the total heat load lost to the soil and air using the Agnew approach is plotted in Figure 6. In early 1962, calculated heat losses to the soil and air were approximately 80 percent of the total heat. Clearly, as one moves into the quiescent time period, uncertainties in the heat loss to the soil and air have an increasing impact on the uncertainties of leak volume estimates.

\subsection{TANK TEMPERATURE USED IN HLM.}

The temperatures reported in the HLM document for tank SX-108 (Agnew and Corbin 1998) appear to be maximums for the time period and clearly do not reflect tank supernatant liquid temperatures. The temperature data reported by Agnew and Corbin (1998) for tank SX-108 for the period between January 1959 and April 1962 are plotted in Figure 4 and seem to reflect abrupt changes that are likely associated with instrumentation problems rather than real variation in sludge temperature. These values most likely reflect sludge temperatures in the bottom of the tank. The boiling point for the supernatant assumed to have leaked from tank SX-108 (for tank SX-108 waste composition estimates, see Tables 4 and 5 from Agnew and Corbin 1998) is about $110^{\circ} \mathrm{C}$ at 1 atm (Jansen 1966). Only under a significant hydraulic head ( 3 atm) could the boiling point approach $140^{\circ} \mathrm{C}$. However, during operations in boiling waste tanks air circulators were used to mix the supernatant to minimize superheating. Thus, the supernatant temperature was likely to be reasonably homogeneous and near $110^{\circ} \mathrm{C}$ as long the liquid was boiling. This assumption was used by Jansen et al. (1966) in their thermal transport modeling. 
Figure 6. Tank SX-108 Heat Load and Percent Heat Lost to Air and Soil.

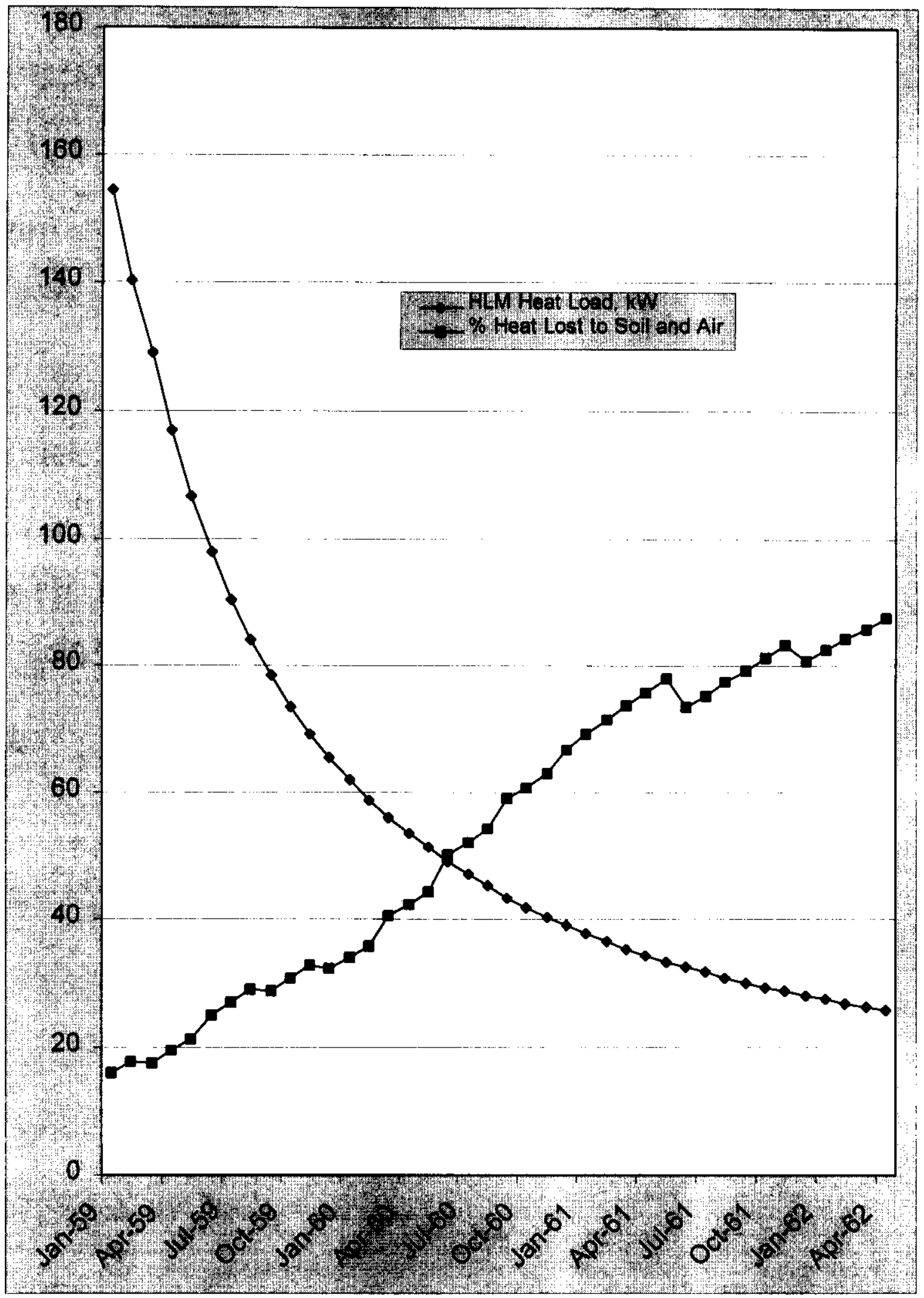


A key point is that, without superheating, the temperature of a well-mixed supernatant cannot increase unless it self-concentrates (i.e., the concentration of ions in solution increase). The supernatant temperature is fixed by the boiling point of the supernatant, which is controlled by the concentration of ions in solution. The evaporative cooling in the boiling waste tanks is analogous to evaporation in a pot of boiling water. Increasing the heat does not increase the water temperature, but rather increases the rate at which water evaporates from the pot. Thus, the quantity of heat transfer to the soil should have been relatively constant. As previously noted, heat losses to the air are less well defined.

\subsection{UNCERTAINTIES IN LATENT HEATS OF VAPORIZATION}

Quantifying the volume of water lost as a function heat loss is directly related to the value for the "latent heat of vaporization" for the supernatant. The latent heat of vaporization for pure water was used in the HLM water loss calculations (Agnew and Corbin 1998). Given the large impact of dissolved salts on the activity of water, we can reasonably question the validity of using the latent heat of vaporization for pure water to estimate evaporative cooling water losses from HLW supernatant liquids. However, apparently, this aspect of solution thermodynamics has not been extensively explored. At least, classic chemical thermodynamics texts dealing with electrolyte solutions (e.g., Lewis and Randall 1961, Klotz 1963, Harned and Owens 1958) do not address the effects of dissolved salts on the latent heat of vaporization.

The latent heat of vaporization for the supernatant liquid in tank SX-108 (Agnew and Corbin 1998) was estimated to be about 7 percent higher than the value for pure water at 1 atm using the Environmental Simulation Program (ESP 1998), the accepted Hanford Site solution thermodynamics computer model (Graham MacLean, private communication). Under a $9 \mathrm{~m}$ (30-ft) hydraulic head, the latent heat of vaporization for REDOX boiling waste would be approximately 4 percent lower than the value for pure water. Thus, it appears the decision to use of the latent heat of vaporization for pure water in the HLM leak volume estimates was reasonable. In addition, any error in the latent heat of vaporization would be systematic and would apply proportionally to all calculations of volume loss from evaporative cooling.

\subsection{MATERIAL BALANCE DURING QUIESCENT PERIOD}

The data included in Table 1 coupled with heat loss estimates developed by Agenw and Corbin (1998) and listed in Table 2 appear to be sufficient to calculate expected tank volumes monthly. Over the period for which monthly tank volume measurements are available (see Table 1), calculated tank volumes can be compared with measured tank volumes. This comparison appears to be sufficient to evaluate potential leaks in tank SX-108 over the quiescent period. These calculations are described in the following paragraphs.

In this document's material balance calculations, the measured tank volume (see Table 1) is assumed to represent the tank volume at the beginning of the month. The volume of liquids added to the tank during the month is added to the beginning tank volume. The estimated water loss to evaporative cooling is then calculated by dividing the heat load by the latent heat of vaporization, including appropriate conversion factors. The calculated tank volumes were 
determined by subtracting the evaporative cooling volume losses from the tank waste volume. These calculations are as follows:

Evaporative Cooling

Volume Loss, $\mathrm{kgal}=$ [Total Heat Load, $\mathrm{kW}$-Heat Loss to Soil and Air, $\mathrm{kW}$ ]

[Latent Heat of Evaporation, $\mathrm{kW} / \mathrm{kgal}]$

Calculated Tank Volume, kgal = Measured Tank Volume, kgal + Volume Added, kgal -

Evaporative Cooling Losses, kgal

Example calculation for the month of January 1959 using HLM heat load estimates:

Evaporative Cooling

Volume Loss, kgal $=\frac{(154.4 \mathrm{~kW}-12.5 \mathrm{~kW}-12.4 \mathrm{~kW}) \text { month }}{\underline{2.259 \mathrm{~kJ} / \mathrm{g} \times 3.785 \mathrm{E} 06 \mathrm{~g} / \mathrm{kgal}}} \times \frac{\mathrm{kJ} / \mathrm{sec}}{\mathrm{kW}}$

$2.625 \mathrm{E} 06 \mathrm{sec} / \mathrm{month}$

Evaporative Cooling Volume Loss, $=39.76 \mathrm{kgal}$

Calculated HLM Tank Volume $=780 \mathrm{kgal}+18 \mathrm{kgal}-39.76 \mathrm{kgal}=758 \mathrm{kgal}$

The calculated monthly tank volumes using the HLM heat load estimates are listed in column 6 of Table 3. The calculated monthly tank volumes using the check heat load estimates are listed in column 7 of Table 3. The measured and calculated tank volumes (columns 1, 2, 5, and 6 of Table 3) are plotted in Figure 7. The calculated tank volumes track each other, as expected based on very similar heat load estimates; the difference between the calculated and measured tank volumes appears to be random.

The HLM-tank volume difference (column 8 of Table 3 ) and the Check-tank volume difference (column 9 of Table 3) were calculated by subtracting the "calculated" tank volume from the next month's measured tank volume. For example, the January 1959 calculated HLM tank volume was $2869 \mathrm{~kL}$ ( $758 \mathrm{kgal})$, based on the beginning monthly tank volume, liquid additions, and evaporative cooling losses. The measured tank volume for February 1959 (assumed to represent the tank volume at the beginning of the next month) was $2922 \mathrm{~kL}$ (772 kgal). Thus, the HLMtank volume difference was $2922 \mathrm{~kL}$ ( $772 \mathrm{kgal})-2869 \mathrm{~kL}$ ( $758 \mathrm{kgal})$ or $53 \mathrm{~kL}$ (14 kgal). That is, on February 1, 1959, the tank contained $53 \mathrm{~kL}(14 \mathrm{kgal})$ more waste than was calculated to be in the tank. It follows, then, that negative tank volume differences might represent a volume leaked from the tank. The HLM-tank volume difference is plotted as a function of time in Figure 8. 
Figure 7. Calculated and Measured Waste Volumes in Tank SX-108.

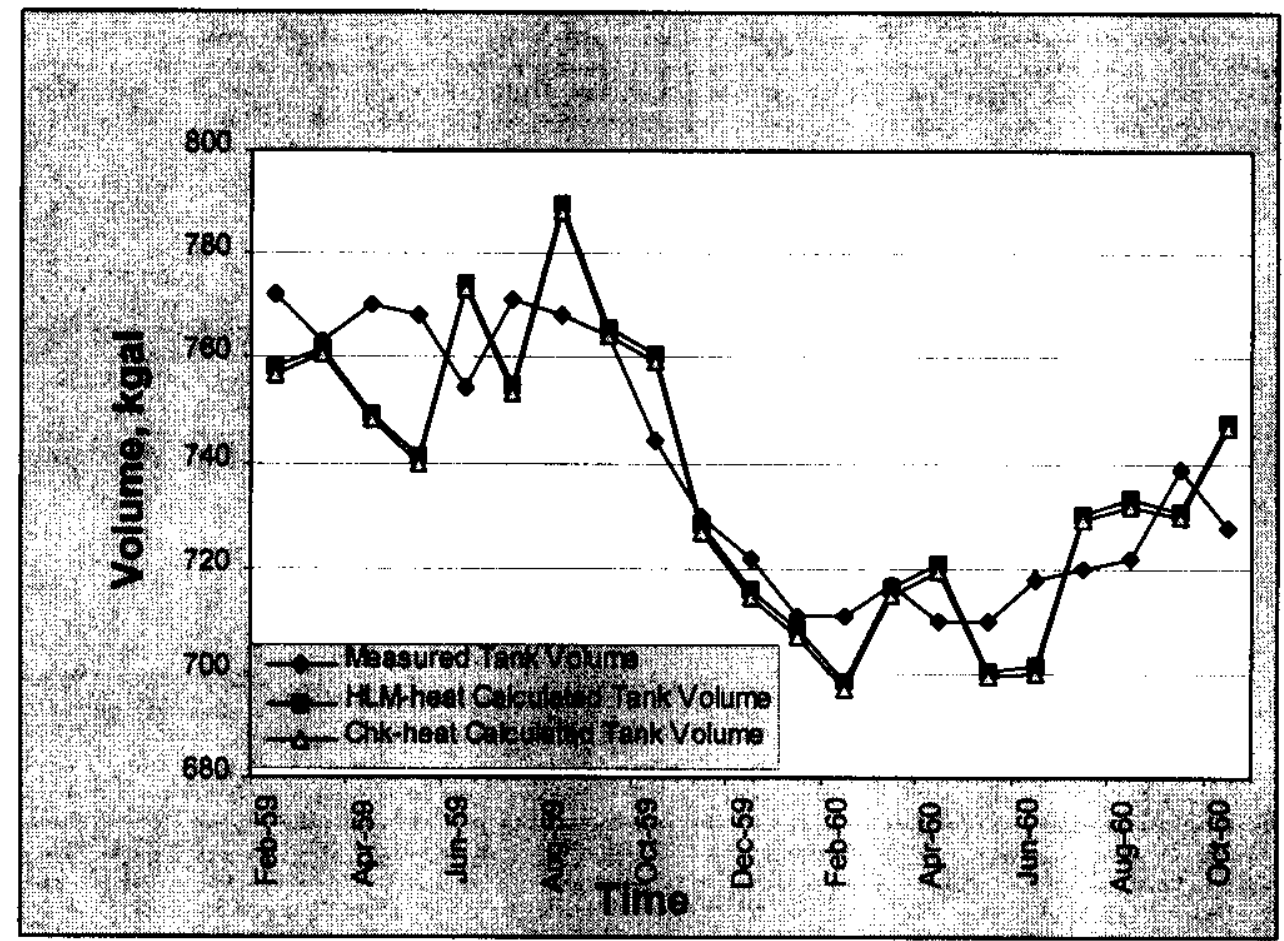

Figure 8. Tank Volume Difference.

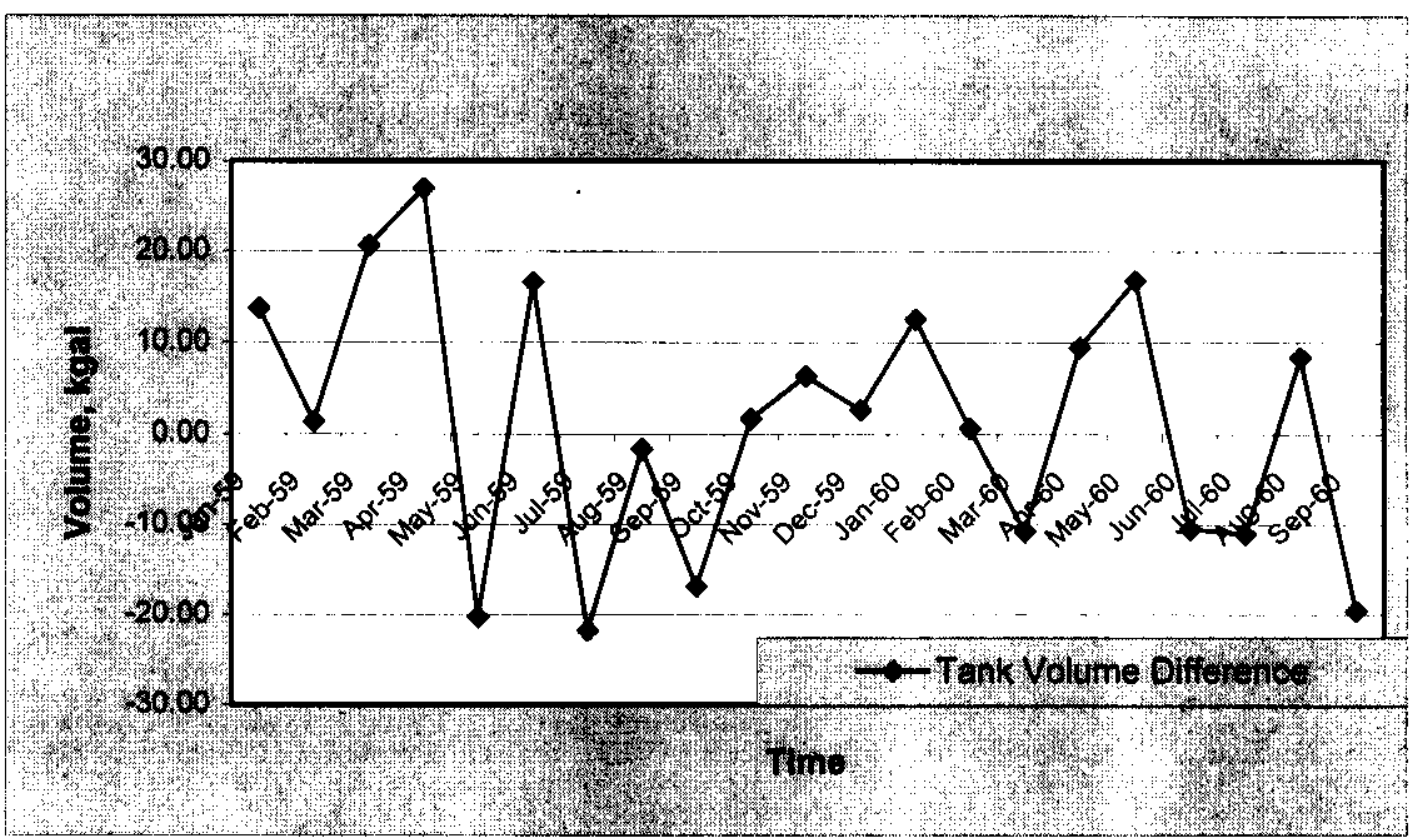


The mean of the HLM-tank volume difference from January 1959 through September 1960 is $4542 \mathrm{~L}(1.2 \mathrm{kgal})$ with a standard deviation of $5451 \mathrm{~kL}(14.4 \mathrm{kgal})$. That is, over a 21 -month period, the average difference between the calculated tank volume and the measured tank volume was $4542 \mathrm{~L}$ (1.2 kgal). However, the standard deviation of $5451 \mathrm{~kL}$ (14.4 kgal) reflects a large scatter in the monthly values. Based on these data, it appears to be impossible to postulate a tank leak over the period from January 1959 through September 1960.

Clearly, the assumption that the measured tank volume represents the tank volume at the beginning of the month could be, and in many cases probably was, not valid. That is, within a month, liquids could have been added before the tank volume measurement rather than after, as was assumed. Thus, comparing one month's Tank Volume Difference with the next month's may not be valid. For example, the large swings observed in the Tank Volume Differences between March and October 1959 (see columns 8 and 9 of Table 3) could reflect times when the assumption is invalid. However, data comparisons over several months should be valid.

A second mass balance calculation was completed for the period of January 1959 through December 1961, the last measured tank volume in the period of interest. The total volume of water lost through evaporative cooling was $1533 \mathrm{~kL}$ (405 kgal) based on the HLM heat loads and $1669 \mathrm{~kL}$ (441 kgal) based on the check heat loads (see columns 3 and 4 of Table 3 ). The measured tank volume decreased $303 \mathrm{~kL}(80 \mathrm{kgal}$ ) (see column 2 of Table 3) and $1298 \mathrm{~kL}$ (343 kgal) of liquid (see column 5 of Table 3 ) were added back to tank SX-108 over the period of interest. Thus, the material balance would be:

Material Balance $=$ Evaporative cooling volume loss $-[$ tank volume change + total volume added back to tank].

For the HLM system:

Material balance $=405 \mathrm{kgal}-[80 \mathrm{kgal}+343 \mathrm{kgal}]=-18 \mathrm{kgal}$

That is, for material balance, the tank would require $68 \mathrm{~kL}$ (18 kgal) more_volume than the December 1961 tank level measurement indicates.

For the check system:

$$
\text { Material balance }=441 \mathrm{kgal}-[80 \mathrm{kgal}+343 \mathrm{kgal}]=18 \mathrm{kgal}
$$

That is, for material balance, the tank would require $68 \mathrm{~kL}(18 \mathrm{kgal})$ less volume than the December 1961 tank level measurement indicates.

The $\pm 68 \mathrm{~kL}$ ( $\pm 18 \mathrm{kgal}$ ) difference between the calculated and measured tank volume appears to be well within the uncertainties suggested by the data in columns 8 and 9 of Table 3 . For the period when monthly measured tank volumes were available, the standard deviation for the average difference between the measured and calculated tank volume change was $5451 \mathrm{~kL}$ (14.4 kgal). Qualitatively, it follows that, for a monthly difference greater than $110 \mathrm{~kL}(29 \mathrm{kgal})$, one would be required to be 95 percent confident that the observed difference was large enough to suggest a potential tank leak. Thus, the overall volume loss of $68 \mathrm{~kL}$ (18 kgal) as suggested 
by the HML system material balance would not qualify as indicating a tank leak, even if that change had occurred in 1 month, much less over 24 months.

\subsection{CONCLUSSIONS}

Much of the data reported in Agnew and Corbin (1998) and this assessment agree closely. As previously noted, the heat load estimates agree very well, but the small differences that were found translate into something greater than a $3785 \mathrm{~kL} / \mathrm{month}(1 \mathrm{kgal} / \mathrm{month})$ difference in monthly evaporative cooling volume decreases. Using the HML heat loads and other assumptions, identical monthly evaporative cooling volume losses were calculated. The volume additions to tank SX-108 used in this assessment came from Waste Status and Transaction Record Summary (WSTRS Rev.2) (WSTRS), WHC-SD-WM-TI-615, -614, -669, 689, Rev. 2 (Agnew 1995), and are identical with the values reported in Agnew and Corbin (1998) except for two water additions found in WSTRS, Rev. 2, but not in Agnew and Corbin (1998). The differences are found in the monthly "calculated tank waste volume" values. This assessment simply sums monthly gains and losses, whereas Agnew and Corbin (1998) execute a much more complex calculation to obtain a "volume of unaccounted water gain or loss for month-i." (It is important to appreciate that the HLM was developed to account for generalized long-term tank operating conditions in multiple HLW tanks, while this assessment covered only a short quiescent period in a single HLW tank, which allows for simpler calculations.)

The evaluation of tank SX-108 information over the period from January 1959 through December 1961 fails to reveal any evidence suggesting a tank leak. Based on scatter in the data, a monthly volume loss of more than $1098 \mathrm{~kL}$ ( $29 \mathrm{kgal})$ between the calculated and measured tank waste volume would be required to be 95 percent confident that an unexplained volume discrepancy had been noted. Unexplained volume discrepancies continuing over many months may indicate a smaller leak. However, no evidence was found of unexplained volume discrepancies over the time period examined. No attempt was made to quantify the minimal multi-month leak that would have been detected.

Because Agnew based the approximately $757 \mathrm{~kL}$ (200-kgal) leak estimate for tank SX-108 on the data over the time period evaluated in this effort, it appears that the HLM leak volume estimate is not valid. In Agnew and Corbin (1998), the exact calculations used in the HLM methodology are described in terms of EXCEL*spreadsheet equations. Without access to the spreadsheet it was impossible to recreate the results published in Agnew and Corbin (1998). However, it appears likely that the results published by Agnew and Corbin (1998) indicating a leak beginning in July 1959 were an artifact of the HLM calculation methodology.

This evaluation provided some indication of the relative uncertainty associated with data used in the calculation. One might expect a 5- to 10-percent uncertainty in the heat loads based on a combination of OREGIN2 and HDW model runs. The amounts of heat lost to the soil and the air ventilation system are highly uncertain. The tank temperatures used in the HLM SX-108 heat loss calculations are not realistic for REDOX HLW supernatant liquids. There is a lack of understanding in the fundamental thermodynamics data required to quantitatively calculate evaporative heat losses in the REDOX boiling waste tanks. Finally, there is some uncertainty in the measured tank volume values. Raymond and Shdo (1966) assigned a measurement

$\overline{\text { EXCEL }}$ is a trademark of Microsoft corporation. 
uncertainty of $\pm 1.3 \mathrm{~cm}( \pm 0.5 \mathrm{in}$.) to tank level measurements under conditions optimized to evaluate potential tank leaks. This would indicate $\mathrm{a} \pm 520 \mathrm{~kL}( \pm 1.375 \mathrm{kgal})$ uncertainty in tank volume measurements. Realistic estimates of uncertainties in waste level measurements under routine operating conditions are not available. These, as yet, non-quantified uncertainties would seem to present a significant challenge in pursuing the HLM approach for estimating leak volumes in high-heat waste tanks.

It should be noted this assessment reevaluated only a small fraction of the data included in the HLM report for tank SX-108. The Agnew report also addressed 3 other REDOX boiling waste tanks. Clearly, addition data reevaluation would be appropriate.

\subsection{REFERENCES}

Agnew, S. F., 1995, Waste Status and Transaction Record Summary (WSTRS Rev. 2), WHC-SD-WM-TI-615, -614, -669, 689, Rev. 2, prepared by Los Alamos National Laboratory, Los Alamos, New Mexico, for Westinghouse Hanford Company, Richland, Washington.

Agnew, S. F., and R. A. Corbin, 1998, Analysis of SX Farm Leak Histories-Historical Leak Model (HLM), LA-UR-96-3537, Los Alamos National Laboratory, Los Alamos, New Mexico.

ESP, 1998, Environmental Simulation Program, Version 6.0, ORI Systems, Inc., Morristown, New Jersey.

Harned, H. S., and B. B. Owen, 1958, The Physical Chemistry of Electrolytic Solutions, third edition, Reinhold Publishing Corporation, New York, New York.

Hanlon, B. M., 1999, Waste Tank Summary Report for Month Ending April 30, 1999, HNF-EP-0182-133, prepared by Lockheed Martin Hanford Corporation for Fluor Daniel Hanford, Inc., Richland, Washington.

Jansen, Jr., G., 1964, Thermal Consequences of Leaks in Radioactive Waste Storage Tanks, HW-80848, Hanford Atomic Products Operation, Richland, Washington.

Jansen, Jr., G., W. E. Willingham, and W. V. DeMier, 1966, Buried Radioactive Waste Storage Tank Temperatures Near Leaks, BNWL-181, Pacific Northwest Laboratory, Richland, Washington.

Klotz, I. M., 1964, Chemical Thermodynamics, Basic Theory and Methods, Revised Edition, W. A. Benjamin, Inc, New York, New York.

Kupfer, M. J., A. L. Boldt, K. M. Hodgson, L. W. Shelton, B. C. Simpson, R. A. Watrous, M. D. LeClair, G. L. Borsheim, R. T. Winward, B. A. Higley, R. M. Orme, N. G. Colton, S. L. Lambert, D. E. Place, and W. W. Schulz, 1998, Sandard Inventories of Chemicals and Radionuclides in Hanford Site Tank Wastes, HNF-SD-WM-TI-740, Rev. 8, prepared 
by Lockheed Martin Hanford Corporation for Fluor Daniel Hanford, Inc., Richland, Washington.

Lewis, G. N., and M. Randall, 1961, Thermodynamics, Second Edition, revised by K. S. Pitzer, McGraw-Hill Book Company, New York, New York.

Lewis, W. S., 1992, "241-SX-109 Leak Volume," contained in Waste Tank 241-SX-109, Supporting Documentation, Miscellaneous Reports, Letters, Memoranda, and Data, compiled by E. H. Neilsen, WHCMR-0301, Westinghouse Hanford Company, Richland, Washington.

Metcalf \& Eddy, Inc., 1991, Wastewater Engineering, Treatment, Disposal, and Reuse, Third Edition, Revised by G. Tchobanoglous, McGraw-Hill, Inc., New York, New York.

Willingham, W. E., and G. Jansen, Jr., 1966, Heat Transfer from Solidified Wastes in Underground Storage Tank, BNWL-262, Pacific Northwest Laboratory, Richland, Washington.

Wooten, D. W., 1998, Evaluation of Historical Leak Model for Tank SX-108 Decay Power, Fluor Daniel Northwest, Inc., delivered under correspondence number FDNW-RJP-98-025, to Fluor Daniel Hanford, Inc., Richland, Washington. 
APPENDIX A

EVALUATION OF HISTORICAL LEAK MODEL FOR TANK SX-108 DECAY POWER

A-1 
HNF-4756, Rev. 0

This page intentionally left blank.

A-2 
FLUOR DANIEL NORTHWEST, INC.

P. O. Box 1050

1100 Jadwin

Richlond, Woshingtion $99352-1050$

FDNW-RJP-98-025

August 3, 1998

Mr. Jerry W. Cammann

Lockheed Martin Hanford Company

PO Box $1500 \quad$ MSIN R2-11

Richland, Washington 99352-1505

Dear Mr. Cammann:

BEST BASIS INVENTORY DKPRO CODE RUN ADDITIONAL SCOPE - TANK DECAY HEAT CALCULATIONS.

Reference: Letter, C. H. Brevick to L. N. Cortez, "Best Basis Inventory DKPRO Code Run Additional Scope - Tank Decay Heat Calculations", C0-98-TWRS-350, dated July 13, 1998.

The attached report documents studies that Lockheed Martin Hanford Company (LMHC) requested of the Specialty Engineering Department within Fluor Daniel Northwest, Inc. (FDNW) to estimate tank decay heat at times related to leaks from the high heat tank SX-108.

This report completes the deliverables identified in the reference.

Sincerely,

lojplot

RJ Puigh

Manager

Environmental \& Nuclear Initiatives

RJP:DWW:jwh

Attachment
c: With Attachment
D. S. Leach, FDNW
C. H. Brevick, FDNW
R. J. Puigh, FDNW
S. F. Finfrock, FDNW
R. A. Watrous, LMHC
T. E. Jones, MACTC
D.W.Wootan, FDNW $D W \Omega$ 


\section{LBFFER REPORT \\ b. \\ EVALUATION OF FOR TANK SX-108 DECAY POWER}

Prepared by

FLUOR DANIEL NORTHWEST, INC

July 1998

Prepared for

LOCKHEED MARTIN HANFORD COMPANY

Task Order LMHC96WO-0006-04061

Dw Wat

D. W. Wootan, Technical Aythor

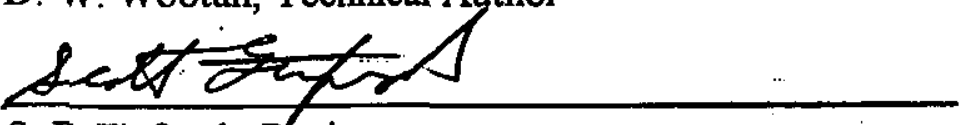

S. F. Finfrock, Reviewer
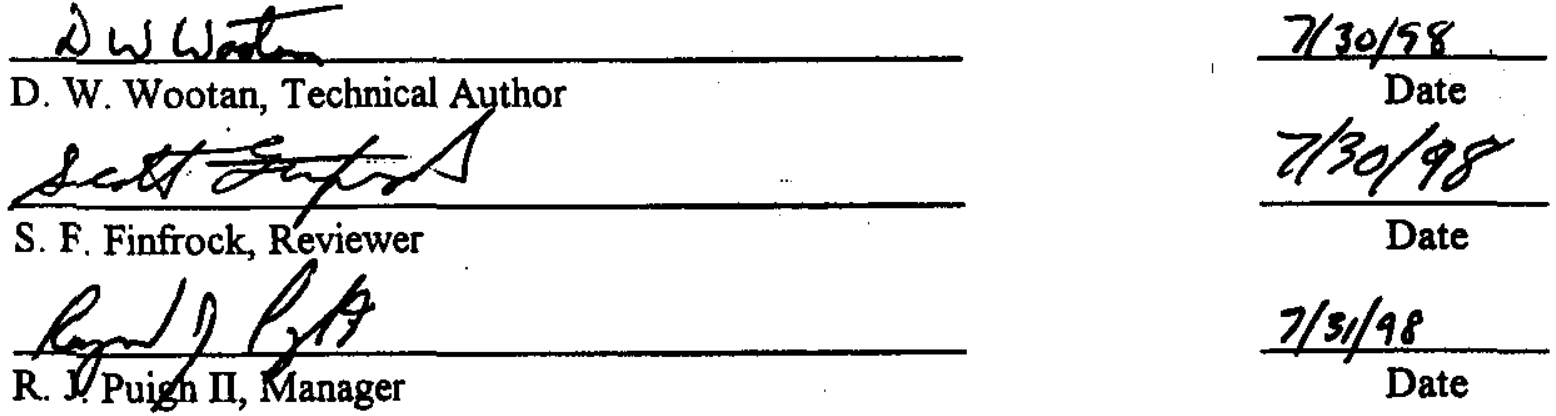

A-4 


\section{Evaluation of Historical Leak Model for Tank SX-108 Decay Power}

Scope

This report evaluates the ability of the Historical Leak Model (HLM), developed by Los Alamos National Laboratory (LANL), to back-calculate the concentrations of heat-producing radionuclides to the precision required to develop realistic estimates of tank leak volumes. Fuel processing and waste addition records were used to calculate the decay heat in the suspected leaking high heat load tank SX-108 during the period 1955 to 1968 for comparison with the FLM estimates.

\section{Background and LANL Methodology}

A Historical Leak Model (Agnew, 1998) was developed by LANL for estimating tank leak volumes from potentjally leaking single-shell tanks that contained high-heat wastes. The approach is based on calculating the difference between the volume of water lost to evaporation versus the amount of water added back to the tank over the period of time the tank was suspected to have leaked. Such calculations require a knowledge of the quantities of heat-producing radionuclides in the tank over the time period of interest.

The Hanford Derived Waste (HDW) Model provides a means to calculate the current composition of the waste in a particular tank based on approximately monthly batch fuel activity records generated using the ORIGEN2 and DKPRO codes (Watrous 1997). However, all of the radionuclide concentrations used in the HDW model had been decayed to January 1,1994 . Also, the major sources of tank decay heat in the first one to six years after fuel discharge, such as ${ }^{144} \mathrm{Ce}$, were not included. The restriction of the fuel activity file to only long-lived radionuclides and their pre-decay to 1994 was done because the original goal of the HDW model was to predict current tank inventories, not historical inventories as a function of time.

The HIM used the ${ }^{137} \mathrm{Cs}$ and ${ }^{90} \mathrm{Sr}$ values from the fuel activity records input to the HDW model as of January 1, 1994 to back calculate the concentrations of short lived radionuclides. For each batch of fuel in the fuel activity records, the 1994 prediction of ${ }^{90} \mathrm{Sr}$ and ${ }^{137} \mathrm{Cs}$ was back decayed to the date of fuel discharge for that batch. ${ }^{90} \mathrm{Sr}$ and ${ }^{137} \mathrm{Cs}$ curies were converted to decay heat using watt/Ci factors. An effective cooling curve was derived by LANL by fitting an ORIGEN2 calculation of spent fuel heat generation decay and scaling relative to ${ }^{137} \mathrm{Cs}$ and ${ }^{90} \mathrm{Sr}$. Decay power was defined in terms of four "surrogate" nuclides having half-lives of $1.0,0.45$, 0.22 , and 0.080 years and generating $12.9,15.0,108$, and 200 watts per watt of ${ }^{90} \mathrm{Sr}-\mathrm{Y} /{ }^{137} \mathrm{Cs}-\mathrm{Ba}$ at time of fuel discharge. Total decay heat at discharge was calculated by multiplying the ${ }^{90} \mathrm{Sr}-\mathrm{Y}$ and ${ }^{137} \mathrm{Cs}-\mathrm{Ba}$ total watts by the watts/watt factors to get the decay power of the surrogate fission products. Decay power accumulated in any tank was then calculated by decaying the surrogate fission product heat for each batch of fuel forward in time to the desired decay date. It was also necessary to account for the accumulation of decay power from multiple fuel batches and waste batches that were routed to more than one receiver tank in a single month. The information in the 
HLM on transfers into and between tanks was apparently only available on a quarterly or semiannual basis, and the same transfer factors were used for each month in the transfer period.

\section{Decay Power Profile}

ORIGEN2 output for typical reactor conditions and fuel types being processed through the REDOX plant were used to check the validity of the HLM methodology for estimating the decay heat of tank waste. ORIGEN2 was used to calculate the radionuclide production during fuel irradiation and the subsequent radioactive decay for enriched single pass reactor fuel with fuel exposures ranging from approximately 200 to 1400 MWD/MT. Figures 1 and 2 compare the HLM prescription (from Agnew 1998) for generating fuel decay heat with these ORIGEN2 predictions for fuel with low, average, and high exposures. These decay curves have been normalized to the values at 4000 days decay, where nearly all the decay heat is from ${ }^{137} \mathrm{Cs}$ and ${ }^{90} \mathrm{Sr}$ decay. For average fuel exposures, the HLM decay heat profile agrees with ORIGEN2 to within $5 \%$. However, at decay times of less than 500 days, the HLM predicts too little heat in lower than average exposure fuel and too much heat in higher than average exposure fuel.

\section{Tank SX-108 Decay Power Profile}

Fuel processing records and ORIGEN2 decay heat curves for each fuel batch processed through the REDOX plant and added to tank SX-108 for the waste accumulation period of 19591964 were used to calculate the complete radionuclide inventory and decay heat for tank SX-108 at monthly intervals from 1956 to 1967 . Both the HLM and this check calculation used the WSTRS data file to determine time periods when REDOX waste was being routed to Tank SX108. Table 1 lists information on the fuel batches including specific information on the amount of fuel in metric tons (MT), the fuel exposure in MWD/MT, the fuel cooling time (from Watrous 1997), and the fraction of the waste from that batch of fuel that was added to tank SX-108 (from Agnew 1998). Duplicate months in Table 1 indicate that two fuel batches were processed that month. Separate ORIGEN2 calculations were made for each batch of fuel added to the tank during this period, using the data in Table 1 and an average specific power of $10 \mathrm{MW} / \mathrm{MT}$. Radionuclide concentrations and decay heat for each batch of fuel were calculated at various decay times following the end of irradiation, ranging from 50 to 4000 days. ORIGEN2 could be used to generate the decay heat values on a monthly basis over the entire time period of interest. However, to avoid the large amount of data manipulation involved, the decay power output for each fuel batch was fit to a set of five exponential decay terms with half lives of $30 ., 1 ., 0.8,0.18$, and 0.08 years. Separate fits were made for each fuel batch, which generally achieved $1 \%$ agreement with the ORIGEN2 values between 100 days and 4000 days decay. The fit equations were then used in a spreadsheet to generate monthly decay heat values for each fuel batch. As explained in the following section, adjustments were made for a few waste transfers into and out of the tank.

Figure 3 compares the ORIGEN2 calculated tank power profile ("check") generated to the HLM's tank power estimates for the same period. Figure 4 shows the percent difference in 
HNF-4756, Rev. 0

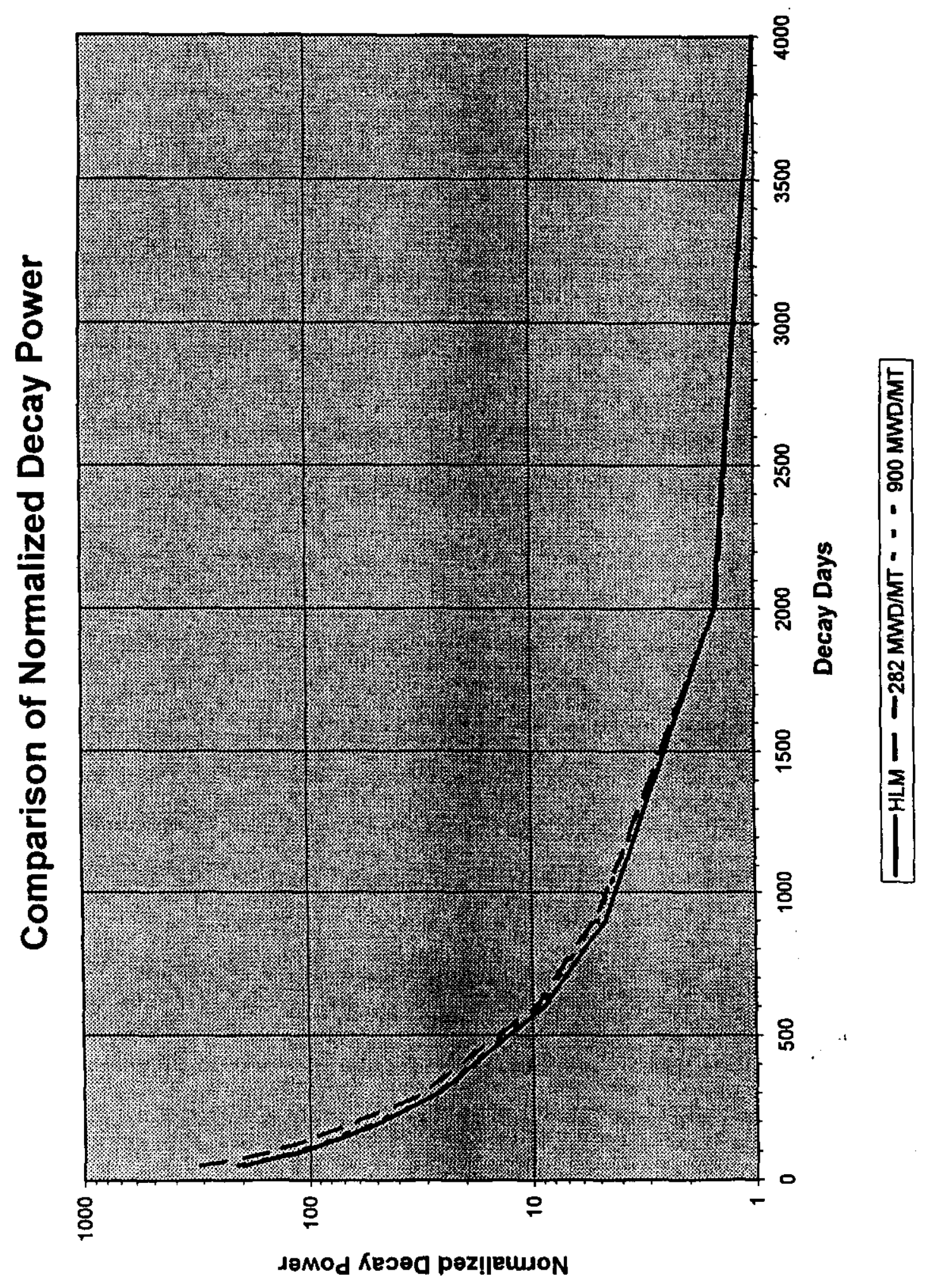

 
HNF-4756, Rev. 0

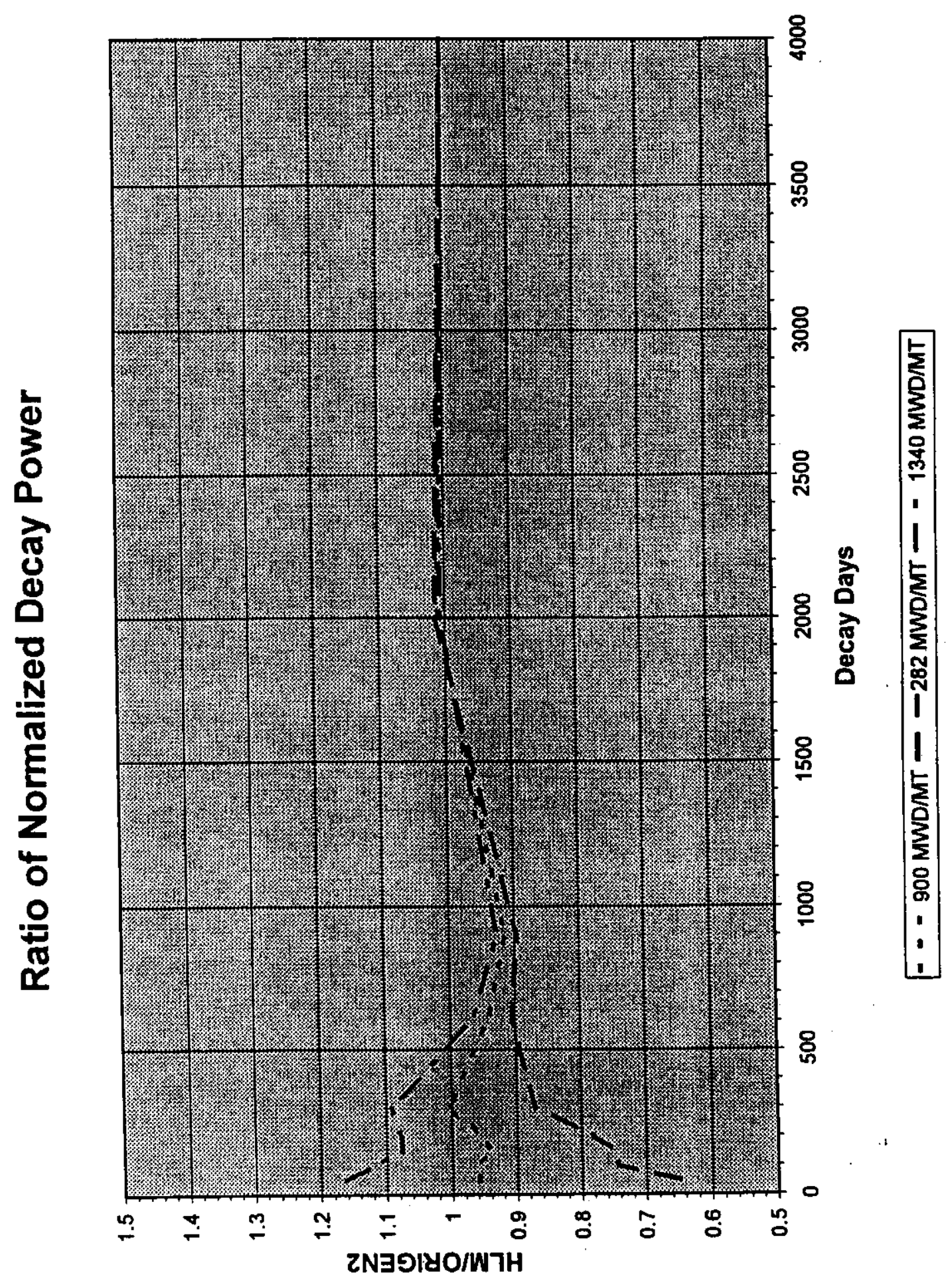

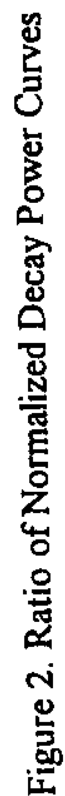


Table 1. Fuel Processing Data For Tank SX-108.

\begin{tabular}{|c|c|c|c|c|c|c|c|c|c|}
\hline \multirow[t]{2}{*}{$\mathrm{KEY}$} & \multirow{2}{*}{$\begin{array}{c}\text { TYPE } \\
\text { OF FUEL }\end{array}$} & \multirow[t]{2}{*}{ MTU } & \multirow[t]{2}{*}{ MWD/MTU } & \multirow[t]{2}{*}{ PLANT } & \multicolumn{2}{|c|}{ SEP.DATE } & \multirow{2}{*}{$\begin{array}{l}\text { SEP. } \\
\text { KEY }\end{array}$} & \multirow{2}{*}{$\begin{array}{c}\text { COOLING } \\
\text { DAYS }\end{array}$} & \multirow{2}{*}{$\begin{array}{c}\text { FR } \\
\text { RADS* }\end{array}$} \\
\hline & & & & & MONTH & YEAR & & & \\
\hline 3937 & AL- $0.71 U$ & 257 & 282 & Redox & 10 & 55 & 4037.01 & 100 & 0.42 \\
\hline 3911 & $\mathrm{AL}-0.71 \mathrm{U}$ & 215 & 900 & Redox & 11 & 55 & 4068.01 & 157 & 0.42 \\
\hline 3997 & $\mathrm{AL}-0.71 \mathrm{U}$ & 139 & 1000 & Redox & 12 & 55 & 4098.01 & 101 & 0.42 \\
\hline 4075 & $\mathrm{AL}-0.71 \mathrm{U}$ & 182 & 904 & Redox & 4 & 56 & 4220.02 & 145 & 0.10 \\
\hline 4141 & Al $-0.71 \mathrm{U}$ & 194 & 843 & Redox & 5 & 56 & 4250.02 & 109 & 0.10 \\
\hline 4171 & $\mathrm{Al}-0.71 \mathrm{U}$ & 149 & 780 & Redox & 6 & 56 & 4281.02 & 110 & 0.10 \\
\hline 4187 & AL $-0.71 \mathrm{U}$ & 54 & 827 & Redox & 7 & 56 & 4311.02 & 124 & 0.12 \\
\hline 4208 & $\mathrm{AL}-0.71 \mathrm{U}$ & 95 & 289 & Redox & 8 & 56 & 4342.02 & 134 & 0.12 \\
\hline 4224 & AL $-0.71 U$ & 219 & 278 & Redox & 9 & 56 & 4372.02 & 148 & 0.12 \\
\hline 4371 & $\mathrm{Al}-0.71 \mathrm{U}$ & 73 & 763 & Redox & 1 & 57 & 4494.02 & 123 & 1.00 \\
\hline 4404 & $\mathrm{AL}-0.71 \mathrm{U}$ & 102 & 704 & Redox & 2 & 57 & 4524.02 & 120 & 1.00 \\
\hline 4427 & $A L-0.71 \mathrm{U}$ & 82 & 625 & Redox & 3 & 57 & 4555.02 & 128 & 0.60 \\
\hline 4658 & $\mathrm{AL}-0.71 \mathrm{U}$ & 165 & 690 & Redox & 10 & 57 & 4768.02 & 110 & 0.40 \\
\hline 4695 & AL- $-0.71 \mathrm{U}$ & 148 & 641 & Redox & 11 & 57 & 4798.02 & 103 & 0.40 \\
\hline 4729 & AL $-0.71 \mathrm{U}$ & 229 & 436 & Redox & 12 & 57 & 4829.02 & 100 & 0.40 \\
\hline 4966 & AL-0.71U & 109 & 604 & Redox & 8 & 58 & 5072.02 & 106 & 0.01 \\
\hline 4930 & AL $-0.71 \mathrm{U}$ & 12 & 855 & Redox & 10 & 58 & 5133.02 & 203 & 1.00 \\
\hline 4930 & $\mathrm{AL}-0.94 \mathrm{U}$ & 8 & 437 & Redox & 10 & 58 & 5133.03 & 203 & 1.00 \\
\hline 4952 & $\mathrm{AL}-0.94 \mathrm{U}$ & 6 & 1339 & Redox & 11 & 58 & 5163.02 & 211 & 1.00 \\
\hline 4975 & $\mathrm{AL}-0.94 \mathrm{U}$ & 68 & 816 & Redox & 12 & 58 & 5194.02 & 219 & 1.00 \\
\hline 5016 & $\mathrm{AL}-0.94 \mathrm{U}$ & 63 & 956 & Redox & 1 & 59 & 5224.02 & 208 & 0.09 \\
\hline 4977 & $\mathrm{AL}-0.94 \mathrm{U}$ & 49 & 711 & Redox & 2 & 59 & 5255.02 & 278 & 0.09 \\
\hline 5035 & AL- $0.94 \mathrm{U}$ & 46 & 782 & Redox & 3 & 59 & 5285.02 & 250 & 0.09 \\
\hline 6359 & $\mathrm{AL}-0.94 \mathrm{U}$ & 102 & 819 & Redox & 9 & 62 & 6564.02 & 205 & 0.53 \\
\hline 6367 & $\mathrm{AL}-0.94 \mathrm{U}$ & 99 & 890 & Redox & 10 & 62 & 6594.02 & 227 & 1.00 \\
\hline 6398 & $A L-0.94 \mathrm{U}$ & 51 & 919 & Redox & 11 & 62 & 6624.02 & 226 & 1.00 \\
\hline 6459 & $\mathrm{AL}-0.94 \mathrm{U}$ & 43 & 887 & Redox & 12 & 62 & 6655.02 & 196 & 1.00 \\
\hline 6615 & $\mathrm{AL}=0.94 \mathrm{U}$ & 167 & 902 & Redox & 4 & 63 & 6777.02 & 162 & 0.55 \\
\hline 6645 & AL $0.94 U$ & 22 & 911 & Redox & 5 & 63 & 6807.02 & 162 & 0.55 \\
\hline 6685 & $\mathrm{AL}=0.94 \mathrm{U}$ & 117 & 925 & Redox & 6 & 63 & 6837.02 & 152 & 0.55 \\
\hline 6637 & $\mathrm{AL}=0.94 \mathrm{U}$ & 139 & 963 & Redox & 7 & 63 & 6868.01 & 231 & 1.00 \\
\hline 6589 & AL $0.94 \mathrm{U}$ & 114 & 952 & Redox & 8 & 63 & 6898.02 & 309 & 1.00 \\
\hline 6708 & $\mathrm{AL}=0.94 \mathrm{U}$ & 76 & 1066 & Redox & 9 & 63 & 6929.02 & 221 & 1.00 \\
\hline 6790 & AL-0.94U & 38 & 1020 & Redox & 10 & 63 & 6959.02 & 169 & 1.00 \\
\hline 6805 & AL-0.94U & 15 & 970 & Redox & 11 & 63 & 6990.02 & 185 & 1.00 \\
\hline 6805 & ZR-0.94U & 2 & 970 & Redox & 11 & 63 & 6990.03 & 185 & 1.00 \\
\hline 6778 & $\mathrm{AL}-0.94 \mathrm{U}$ & 51 & 873 & Redox & 12 & 63 & 7020.02 & 242 & 1.00 \\
\hline 6770 & Al $-0.94 \mathrm{U}$ & 174 & 920 & Redox & 1 & 64 & 7051.02 & 281 & 0.04 \\
\hline 6859 & $\mathrm{AL}-0.94 \mathrm{U}$ & 155 & 970 & Redox & 2 & 64 & 7081.02 & 222 & 0.04 \\
\hline 6896 & $\mathrm{Al}-0.94 \mathrm{U}$ & 109 & 976 & Redox & 4 & 64 & 7142.02 & 246 & 0.07 \\
\hline 6953 & AL- $0.94 U$ & 164 & 937 & Redox & 5 & 64 & 7172.02 & 219 & 0.07 \\
\hline 7045 & AL_-0.94U & 71 & 966 & Redox & 6 & 64 & 7203.02 & 158 & 0.07 \\
\hline
\end{tabular}

*FR. RADS is the fraction of the waste from each batch of fuel that was added to Tank SX-108. 
HNF-4756, Rev. 0

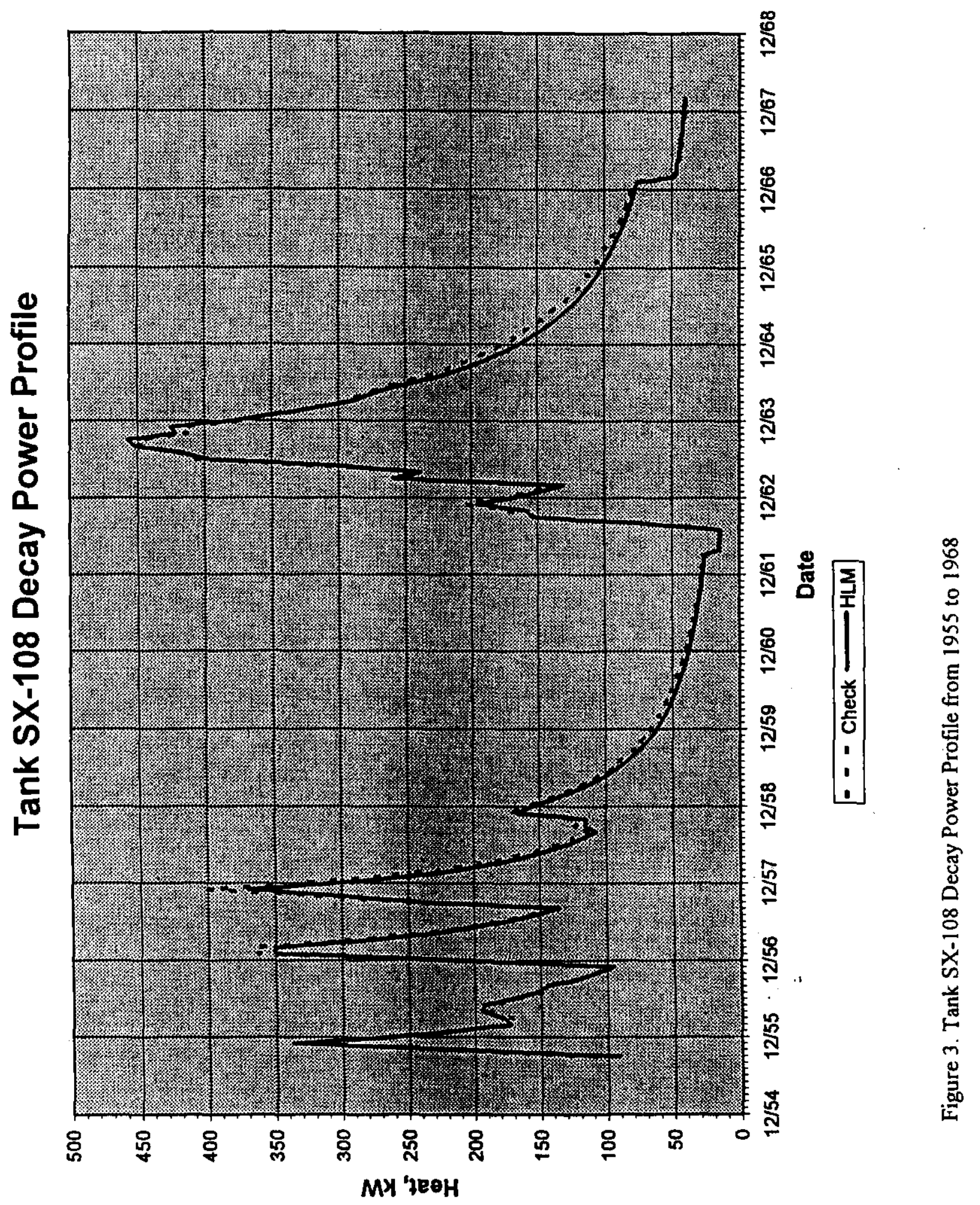




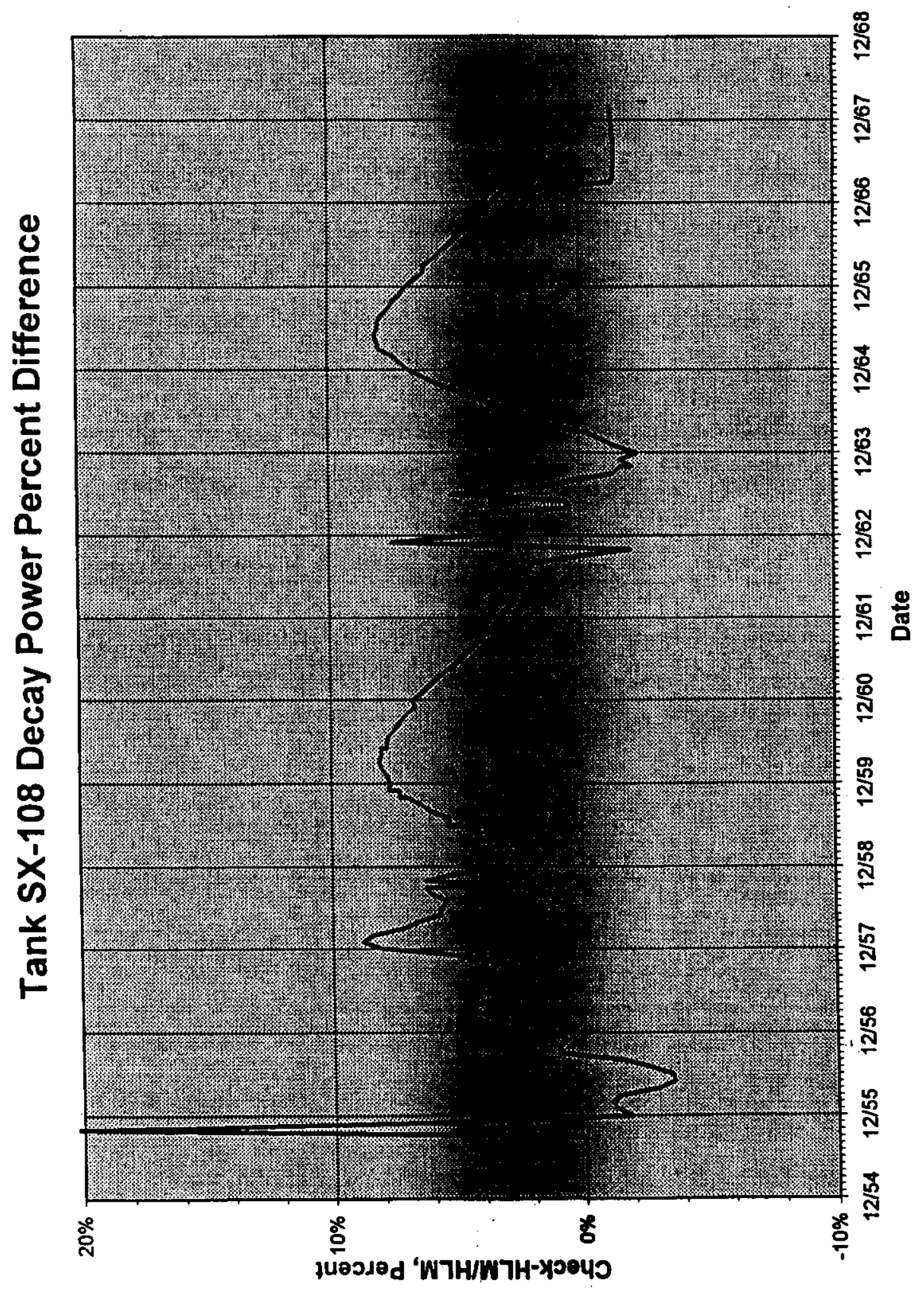

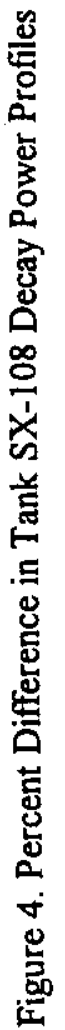




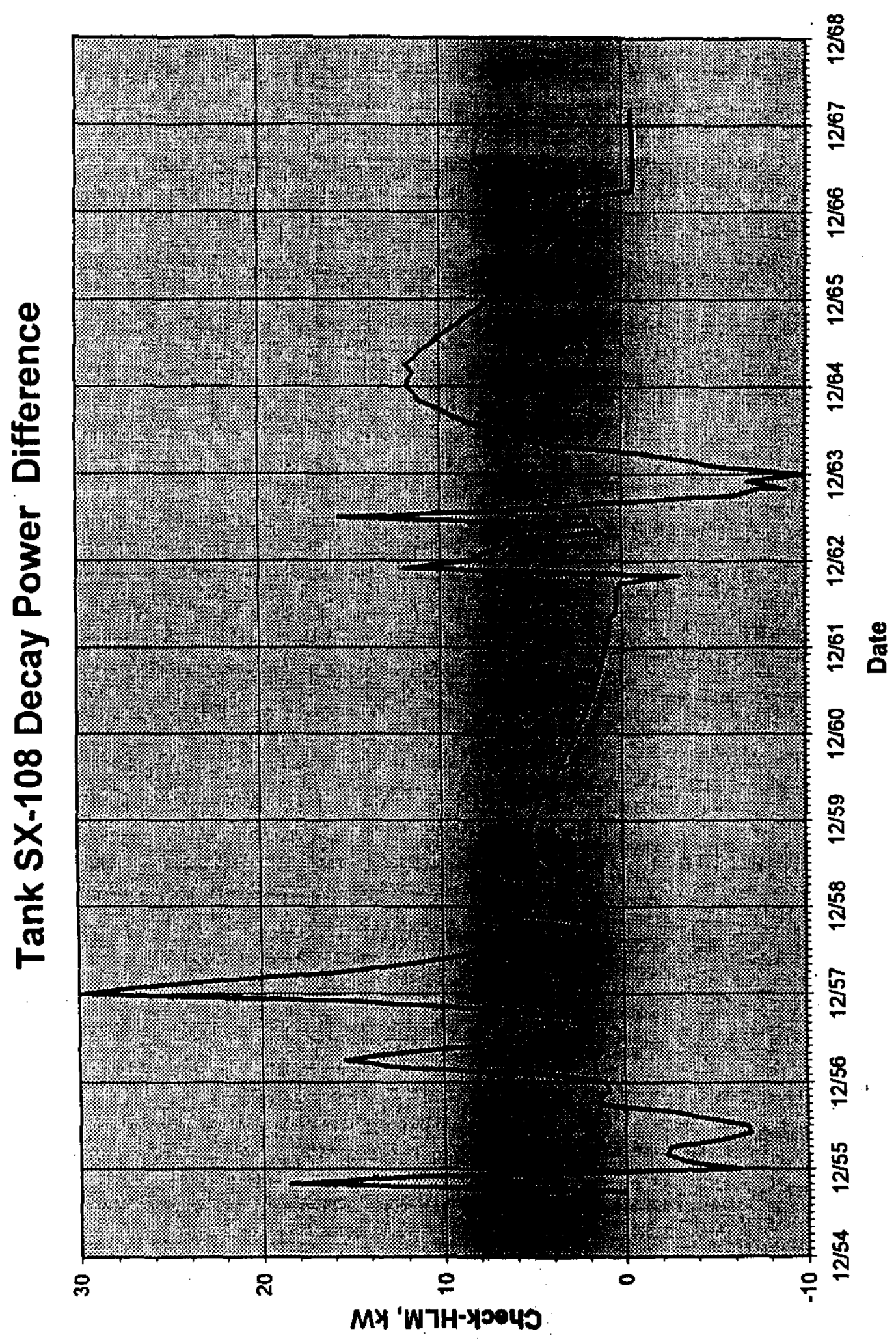

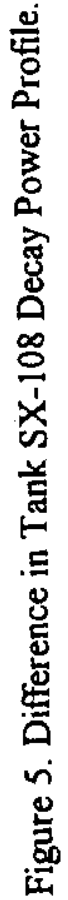


the monthly values from the HLM. Except for one month, the differences were $10 \%$ or less. Figure 5 shows the difference in tank decay heat in $\mathrm{kW}$ on a monthly basis. The higher values of decay heat differences for $10 / 55$ and $12 / 57$ are likely due to the fact that relatively low exposure fuel was processed during those months. As shown in the previous section, the average decay power profile used in the HLM predicts less heat at short decay times for low exposure fuel compared to the ORIGEN2 predictions. The values displayed in Figures 3, 4, and 5 are provided in the Appendix.

\section{Transfers To/from Other Tanks}

Three instances of waste transfers out of Tank SX-108 during the time period of interest were identified in the HLM. For a consistent comparison, a similar partitioning process between supernatant and sludge as that used in developing the HLM was applied. The total heat in the tank was divided into a strontium fraction that stays in the tank and a cesium fraction that goes with the supernatant. The volume reduction was applied only to the cesium fraction. The dates, volume removed (from Agnew 1998), waste volume, and decay heat correction factors are shown in Table 2. The decay heat correction factor is a multiplicative factor applied to the heat in the tank to give the heat remaining at the time of the transfer. Actual distribution of radioisotopes between the sludge and supernatant depends on solubilities and the tank chemistry. Different assumptions about which isotopes were removed with the waste that was pumped out would lead to different values for the amount of heat in the tank following these transfers.

Table 2. Transfers of waste out of Tank SX-108

\begin{tabular}{|c|c|c|c|}
\hline Month/Year & kgal Removed & $\begin{array}{c}\text { kgal Tank Waste } \\
\text { Volume }\end{array}$ & $\begin{array}{c}\text { Decay Heat } \\
\text { Correction Factor }\end{array}$ \\
\hline $5 / 62$ & 665 & 684 & 0.578 \\
\hline $11 / 62$ & 205 & 649 & 0.954 \\
\hline $3 / 67$ & 388 & 565 & 0.610 \\
\hline
\end{tabular}

Three instances of waste transfers into tank SX-108 from tanks other than the condensate return from Tank SX-106 were identified. For lack of any other data on the waste composition being transferred into the tank, the increase in ${ }^{137} \mathrm{Cs}$ inventory during these months from the HLM was converted to decay heat and added to the tank decay heat. This assumption likely under predicts the tank heat since it neglects any additional decay heat from radioisotopes other than ${ }^{137} \mathrm{Cs}$. The dates and amount of heat added (based on Agnew 1998) are listed in Table 3. 
Table 3. Waste Transfers from Other Tanks

\begin{tabular}{|c|c|}
\hline Month/Year & $\mathrm{kW}$ Added \\
\hline $12 / 62$ & 10.3 \\
\hline $6 / 63$ & 6.7 \\
\hline $12 / 63$ & 5.6 \\
\hline
\end{tabular}

\section{Fuel Enrichment}

The fuel processed during 1955-1964 was a mixture of natural and 0.947\% enriched fuel. For an irradiation to the same exposure in $M W D / M T$, differences in decay power between natural and enriched fuel was negligible. This is due to the fact that the decay heat is dominated by the fission products, which would be the same for the range of fuel exposures encountered.

\section{Fuel Specific Power}

An average fuel specific power of 10.MW/MT was used for all of the calculations. The actual specific power of each fuel batch depends on the location in the reactor and the reactor operating conditions, and is not known. The average specific power of the single pass reactor fuel can be inferred from the reactor power level and the total fuel loading, and varied over time as the reactor power was significantly upgraded between the beginning of operations and the end of life. Typical specific powers started about $1 \mathrm{MW} / \mathrm{MT}$ in 1946, steadily increased to about 5 MW/MT by 1955 , and reached 8-10 MW/MT after 1960 . Fuel enriched to $0.947 \%{ }^{235} \mathrm{U}$ operated at specific powers approximately $10 \%$ higher than natural fuel. Lower fuel specific powers require longer irradiations to reach a given fuel exposure in MWD/MT. The number of fissions would be the same, so the production of longer lived fission products such as ${ }^{90} \mathrm{Sr}$ and ${ }^{137} \mathrm{Cs}$ would be unaffected. However, during longer irradiations the shorter-lived fission products would undergo more in-reactor decay, resulting in less decay heat at short decay times. Table 4 compares the decay power following irradiation for a typical fuel exposure of $900 \mathrm{MWD} / \mathrm{MT}$ for specific powers of $5 \mathrm{MW} / \mathrm{MT}$ and $10 \mathrm{MW} / \mathrm{MT}$. At 100 days decay after the end of irradiation, a specific power of $5 \mathrm{MW} / \mathrm{MT}$ would result in a decay power $26 \%$ lower than at $10 \mathrm{MW} / \mathrm{MT}$, while there would be no difference at 4000 days decay. Thus, the impact of using an average specific power of $10 \mathrm{MW} / \mathrm{MT}$ for all of the fuel is that the peaks in decay power (easily seen in Figure 3 ) prior to 1960 are overestimated by as much as $25 \%$. 
Table 4. Impact of Lower Fuel Specific Power on Decay Power

\begin{tabular}{|c|c|}
\hline Decay Time, days & $\begin{array}{c}\text { Decay Power at 5MW/MT } \\
\text { Decay Power at 10MW/MT }\end{array}$ \\
\hline 100 & 0.74 \\
\hline 200 & 0.78 \\
\hline 300 & 0.83 \\
\hline 600 & 0.91 \\
\hline 900 & 0.93 \\
\hline 2000 & 0.98 \\
\hline 4000 & 1.00 \\
\hline
\end{tabular}

\section{Conclusions}

A somewhat independent assessment of the decay power by month in the presumed leaking high heat tank SX-108 between 1955 and 1968 shows general agreement to within $10 \%$ with the HLM. The check values ranged $-4 \%$ to $+9 \%$ from the HIM values, except for one value of $+20 \%$, which corresponded to a batch of low exposure fuel. In terms of decay power, the differences ranged from $-10 \mathrm{~kW}$ to $+30 \mathrm{~kW}$, with the largest differences corresponding to very brief periods after large heat additions. The integrated power over this entire time period was $3 \%$ greater for the check power profile compared to the HIM profile. The HIM's use of a generic fuel decay heat curve was shown to be measurably in error only for decay times of less than 500 days with low or high exposure fuel. The use of an average specific power of $10 \mathrm{MW} / \mathrm{MT}$ for all of the fuel may overestimate the short term peaks in decay power prior to 1960 by as much as $25 \%$.

This assessment was not completely independent because the same fuel batch processing records of fuel amounts, exposures, and cooling times were used as starting points. Also, the same tank transfer fractions were used in both studies, and similar assumptions were used to account for waste transfers to or from other tanks. The assumptions regarding separation of radionuclides between sludge and supernatant for waste transfers to or from a particular tank are very important in determining the heat load of the tank. The evaluation of the accuracy of those assumptions was beyond the scope of this study. 
HNF-4756, Rev. 0

\section{References}

Agnew, S. F., and R. A. Corbin, 1998, Analysis of SX Farm Leak Histories -- Historical Leak Model (HLM), LA-UR-96-3537, Los Alamos National Laboratory, Los Alamos, New Mexico.

Watrous, R. A., and D. W. Wootan, 1997, Activity of Fuel Batches Processed Through Hanford Separations Plants, 1944 Through 1989, HNF-SD-WM-TI-794, Rev. 0, Lockheed Martin Hanford Corporation, Richland, Washington. 
HNF-4756, Rev. 0

\section{Appendix}

Comparison of Check Values and Historical Leak Model Values for SX-108 Decay Power 
Table A-1. Comparison with Historical Leak Model for Tank SX-108 Decay Power

\begin{tabular}{|c|c|c|c|c|}
\hline $\mathrm{Mo} / \mathrm{Yr}$ & $\begin{array}{c}\text { Check, } \\
\mathrm{kW}\end{array}$ & $\begin{array}{l}\text { HLM, } \\
\mathbf{k W}\end{array}$ & $\begin{array}{c}\text { Check-HLM, } \\
\text { kW }\end{array}$ & Check/HLM-l \\
\hline $10 / 55$ & 110.1 & 91.5 & 18.6 & $20.3 \%$ \\
\hline $11 / 55$ & 222.9 & 211.0 & 11.8 & $5.6 \%$ \\
\hline $12 / 55$ & 331.0 & 337.3 & -6.3 & $-1.9 \%$ \\
\hline $1 / 56$ & 259.1 & 262.4 & -3.3 & $-1.2 \%$ \\
\hline $2 / 56$ & 208.3 & 210.5 & -2.3 & $-1.1 \%$ \\
\hline $3 / 56$ & 170.5 & 173.0 & -2.5 & $-1.5 \%$ \\
\hline $4 / 56$ & 172.4 & 177.5 & -5.2 & $-2.9 \%$ \\
\hline $5 / 56$ & 187.3 & 194.3 & -6.9 & $-3.6 \%$ \\
\hline $6 / 56$ & 186.3 & 193.0 & -6.7 & $-3.5 \%$ \\
\hline $7 / 56$ & 168.3 & 172.9 & -4.6 & $-2.6 \%$ \\
\hline $8 / 56$ & 150.3 & 152.7 & -2.4 & $-1.5 \%$ \\
\hline $9 / 56$ & 145.7 & 144.3 & 1.4 & $1.0 \%$ \\
\hline $10 / 56$ & 125.1 & 123.8 & 1.3 & $1.0 \%$ \\
\hline $11 / 56$ & 108.6 & 107.8 & 0.8 & $0.8 \%$ \\
\hline $12 / 56$ & 96.1 & 94.9 & 1.1 & $1.2 \%$ \\
\hline $1 / 57$ & 219.8 & 215.7 & 4.1 & $1.9 \%$ \\
\hline $2 / 57$ & 362.8 & 350.7 & 12.1 & $3.4 \%$ \\
\hline $3 / 57$ & 365.9 & 350.6 & 15.4 & $4.4 \%$ \\
\hline $4 / 57$ & 298.9 & 286.1 & 12.8 & $4.5 \%$ \\
\hline $5 / 57$ & 247.2 & 239.2 & 8.1 & $3.4 \%$ \\
\hline $6 / 57$ & 209.5 & 203.6 & 5.9 & $2.9 \%$ \\
\hline $7 / 57$ & 180.4 & 175.9 & 4.5 & $2.6 \%$ \\
\hline $8 / 57$ & 157.1 & 153.9 & 3.2 & $2.1 \%$ \\
\hline $9 / 57$ & 139.2 & 136.0 & 3.2 & $2.4 \%$ \\
\hline $10 / 57$ & 250.4 & 242.1 & 8.2 & $3.4 \%$ \\
\hline $11 / 57$ & 323.9 & 308.7 & 15.3 & $5.0 \%$ \\
\hline $12 / 57$ & 399.8 & 369.9 & 29.9 & $8.1 \%$ \\
\hline $1 / 58$ & 325.4 & 299.1 & 26.3 & $8.8 \%$ \\
\hline $2 / 58$ & 270.3 & 249.1 & 21.1 & $8.5 \%$ \\
\hline $3 / 58$ & 227.5 & 212.2 & 15.3 & $7.2 \%$ \\
\hline $4 / 58$ & 196.0 & 183.8 & 12.1 & $6.6 \%$ \\
\hline $5 / 58$ & 170.7 & 161.4 & 9.3 & $5.7 \%$ \\
\hline $6 / 58$ & 151.5 & 143.4 & 8.1 & $5.7 \%$ \\
\hline $7 / 58$ & 135.6 & 128.6 & 7.0 & $5.4 \%$ \\
\hline $8 / 58$ & 125.0 & 117.8 & 7.2 & $6.1 \%$ \\
\hline $9 / 58$ & 113.8 & 107.1 & 6.7 & $6.3 \%$ \\
\hline $10 / 58$ & 118.0 & 115.8 & 2.2 & $1.9 \%$ \\
\hline $10 / 58$ & 123.1 & 115.8 & 7.3 & $6.3 \%$ \\
\hline $11 / 58$ & 120.4 & 114.6 & 5.8 & $5.1 \%$ \\
\hline $12 / 58$ & 172.3 & 167.3 & 5.0 & $3.0 \%$ \\
\hline
\end{tabular}




\begin{tabular}{|c|c|c|c|c|}
\hline $\mathrm{Mo} / \mathrm{Yr}_{\mathrm{r}}$ & $\begin{array}{l}\text { Check, } \\
\mathrm{kW}\end{array}$ & $\begin{array}{l}\text { HLM, } \\
\mathrm{kW}\end{array}$ & $\begin{array}{c}\text { Check-HLM, } \\
\text { kW }\end{array}$ & Check/HLM-1 \\
\hline $1 / 59$ & 158.8 & 154.4 & 4.4 & $2.9 \%$ \\
\hline $2 / 59$ & 144.0 & 140.1 & 3.9 & $2.8 \%$ \\
\hline $3 / 59$ & 133.1 & 129.0 & 4.1 & $3.2 \%$ \\
\hline $4 / 59$ & 120.8 & 116.8 & 4.0 & $3.4 \%$ \\
\hline $4 / 59$ & 120.8 & 116.8 & 4.0 & $3.4 \%$ \\
\hline $5 / 59$ & 111.0 & 106.6 & 4.4 & $4.1 \%$ \\
\hline $5 / 59$ & 111.0 & 106.6 & 4.4 & $4.1 \%$ \\
\hline $6 / 59$ & 102.7 & 98.0 & 4.8 & $4.9 \%$ \\
\hline $7 / 59$ & 95.4 & 90.5 & 4.8 & $5.3 \%$ \\
\hline $7 / 59$ & 95.4 & 90.5 & 4.8 & $5.3 \%$ \\
\hline $8 / 59$ & 89.2 & 84.2 & 5.1 & $6.0 \%$ \\
\hline $9 / 59$ & 83.6 & 78.6 & 5.1 & $6.5 \%$ \\
\hline $10 / 59$ & 78.9 & 73.7 & 5.2 & $7.0 \%$ \\
\hline $11 / 59$ & 74.4 & 69.4 & 5.1 & $7.3 \%$ \\
\hline $11 / 59$ & 74.4 & 69.4 & 5.1 & $7.3 \%$ \\
\hline $12 / 59$ & 70.5 & 65.5 & 5.0 & $7.7 \%$ \\
\hline $12 / 59$ & 70.5 & 65.5 & 5.0 & $7.7 \%$ \\
\hline $1 / 60$ & 66.9 & 62.0 & 4.8 & $7.8 \%$ \\
\hline $2 / 60$ & 63.6 & 58.9 & 4.7 & $8.0 \%$ \\
\hline $3 / 60$ & 60.6 & 56.1 & 4.6 & $8.1 \%$ \\
\hline $4 / 60$ & 57.8 & 53.5 & 4.3 & $8.0 \%$ \\
\hline $5 / 60$ & 55.3 & 51.2 & 4.1 & $8.0 \%$ \\
\hline $6 / 60$ & 52.8 & 49.0 & 3.8 & $7.8 \%$ \\
\hline $6 / 60$ & 52.8 & 49.0 & 3.8 & $7.8 \%$ \\
\hline $7 / 60$ & 50.6 & 47.0 & 3.6 & $7.7 \%$ \\
\hline $8 / 60$ & 48.5 & 45.2 & 3.3 & $7.4 \%$ \\
\hline $9 / 60$ & 46.6 & 43.5 & 3.1 & $7.2 \%$ \\
\hline $10 / 60$ & 44.8 & 41.9 & 2.9 & $7.0 \%$ \\
\hline $11 / 60$ & 43.1 & 40.4 & 2.7 & $6.6 \%$ \\
\hline $12 / 60$ & 41.6 & 39.0 & 2.6 & $6.8 \%$ \\
\hline $1 / 61$ & 40.1 & 37.7 & 2.4 & $6.4 \%$ \\
\hline $2 / 61$ & 38.7 & 36.5 & 2.2 & $6.1 \%$ \\
\hline $3 / 61$ & 37.4 & 35.4 & 2.0 & $5.7 \%$ \\
\hline $4 / 61$ & 36.2 & 34.4 & 1.9 & $5.5 \%$ \\
\hline $5 / 61$ & 35.1 & 33.4 & 1.7 & $5.1 \%$ \\
\hline $6 / 61$ & 34.1 & 32.5 & 1.6 & $4.8 \%$ \\
\hline $7 / 61$ & 33.1 & 31.7 & 1.4 & $4.5 \%$ \\
\hline $8 / 61$ & 32.1 & 30.8 & 1.3 & $4.2 \%$ \\
\hline $9 / 61$ & 31.3 & 30.1 & 1.2 & $4.0 \%$ \\
\hline $10 / 61$ & 30.5 & 29.4 & 1.1 & $3.7 \%$ \\
\hline $11 / 61$ & 29.7 & 28.7 & 1.0 & $3.5 \%$ \\
\hline
\end{tabular}




\begin{tabular}{|c|c|c|c|c|}
\hline $\mathrm{Mo} / \mathrm{Yr}$ & $\begin{array}{l}\text { Check, } \\
\mathrm{kW}\end{array}$ & $\begin{array}{l}\text { HLM, } \\
\mathrm{kW}\end{array}$ & $\begin{array}{c}\text { Check-HLM, } \\
\text { kW }\end{array}$ & Check/HLM-1 \\
\hline $12 / 61$ & 29.0 & 28.1 & 0.9 & $3.2 \%$ \\
\hline $1 / 62$ & 28.3 & 27.5 & 0.8 & $3.0 \%$ \\
\hline $2 / 62$ & 27.7 & 26.9 & 0.8 & $2.9 \%$ \\
\hline $2 / 62$ & 27.7 & 26.9 & 0.8 & $2.9 \%$ \\
\hline $3 / 62$ & 27.1 & 26.4 & 0.7 & $2.7 \%$ \\
\hline $3 / 62$ & 27.1 & 26.4 & 0.7 & $2.7 \%$ \\
\hline $4 / 62$ & 26.6 & 25.9 & 0.7 & $2.5 \%$ \\
\hline $5 / 62$ & 15.1 & 14.7 & 0.3 & $2.2 \%$ \\
\hline $6 / 62$ & 14.8 & 14.5 & 0.3 & $2.2 \%$ \\
\hline $7 / 62$ & 14.5 & 14.2 & 0.3 & $2.1 \%$ \\
\hline $8 / 62$ & 14.3 & 14.0 & 0.3 & $2.0 \%$ \\
\hline $9 / 62$ & 69.0 & 69.0 & 0.0 & $0.1 \%$ \\
\hline $10 / 62$ & 151.0 & 154.1 & -3.1 & $-2.0 \%$ \\
\hline $11 / 62$ & 170.6 & 158.7 & 12.0 & $7.5 \%$ \\
\hline $12 / 62$ & 204.3 & 195.9 & 8.3 & $4.3 \%$ \\
\hline $1 / 63$ & 175.9 & 168.1 & 7.7 & $4.6 \%$ \\
\hline $2 / 63$ & 153.3 & 146.9 & 6.4 & $4.4 \%$ \\
\hline $3 / 63$ & 136.4 & 130.2 & 6.1 & $4.7 \%$ \\
\hline $4 / 63$ & 259.9 & 258.9 & 1.0 & $0.4 \%$ \\
\hline $5 / 63$ & 239.6 & 238.1 & 1.5 & $0.6 \%$ \\
\hline $6 / 63$ & 319.5 & 304.0 & 15.5 & $5.1 \%$ \\
\hline $7 / 63$ & 405.4 & 399.4 & 6.1 & $1.5 \%$ \\
\hline $8 / 63$ & 418.0 & 416.7 & 1.3 & $0.3 \%$ \\
\hline $9 / 63$ & 446.6 & 452.7 & -6.1 & $-1.3 \%$ \\
\hline $10 / 63$ & 449.6 & 457.1 & -7.5 & $-1.6 \%$ \\
\hline $11 / 63$ & 412.7 & 421.6 & -8.9 & $-2.1 \%$ \\
\hline $11 / 63$ & 414.7 & 421.6 & -6.9 & $-1.6 \%$ \\
\hline $12 / 63$ & 415.4 & 425.3 & -9.9 & $-2.3 \%$ \\
\hline $1 / 64$ & 374.0 & 379.5 & -5.5 & $-1.5 \%$ \\
\hline $2 / 64$ & 343.8 & 344.7 & -0.8 & $-0.2 \%$ \\
\hline $4 / 64$ & 293.6 & 289.6 & 3.9 & $1.4 \%$ \\
\hline $5 / 64$ & 283.0 & 277.5 & 5.5 & $2.0 \%$ \\
\hline $6 / 64$ & 269.4 & 263.1 & 6.4 & $2.4 \%$ \\
\hline $7 / 64$ & 250.0 & 241.7 & 8.4 & $3.5 \%$ \\
\hline $8 / 64$ & 233.0 & 223.6 & 9.4 & $4.2 \%$ \\
\hline $9 / 64$ & 218.3 & 208.1 & 10.2 & $4.9 \%$ \\
\hline $10 / 64$ & 205.8 & 194.7 & 11.1 & $5.7 \%$ \\
\hline $11 / 64$ & 194.3 & 183.0 & 11.4 & $6.2 \%$ \\
\hline $12 / 64$ & 184.4 & 172.7 & 11.7 & $6.8 \%$ \\
\hline $1 / 65$ & 175.2 & 163.5 & 11.6 & $7.1 \%$ \\
\hline $2 / 65$ & 166.7 & 155.3 & 11.4 & $7.4 \%$ \\
\hline
\end{tabular}




\begin{tabular}{|c|c|c|c|c|}
\hline $\mathrm{Mo} / \mathrm{Yr}$ & $\begin{array}{l}\text { Check, } \\
\mathrm{kW}\end{array}$ & $\begin{array}{c}\text { FuM } \\
\text { by }\end{array}$ & $\begin{array}{c}\text { Check-HLM, } \\
\text { kW. }\end{array}$ & Check/HLM-1 \\
\hline $3 / 65$ & 159.8 & 1480 & 11.8 & $8.0 \%$ \\
\hline $4 / 65$ & 152.7 & 1414 & 11.3 & $8.0 \%$ \\
\hline $5 / 65$ & 146.3 & 135.3 & 11.0 & $8.1 \%$ \\
\hline $6 / 65$ & 140.3 & 1291 & 10.4 & $8.0 \%$ \\
\hline $7 / 65$ & 134.8 & 1248 & 10.0 & $8.0 \%$ \\
\hline $8 / 65$ & 129.6 & 120.2 & 9.4 & $7.8 \%$ \\
\hline $9 / 65$ & 124.7 & 1160 & 8.8 & $7.6 \%$ \\
\hline $10 / 65$ & 120.3 & 112.0 & 8.3 & $7.4 \%$ \\
\hline $11 / 65$ & 116.1 & 108.4 & 7.7 & $7.1 \%$ \\
\hline $12 / 65$ & 112.3 & 105.1 & 7.2 & $6.9 \%$ \\
\hline $1 / 66$ & 108.6 & 101.9 & 6.7 & $6.5 \%$ \\
\hline $2 / 66$ & 105.1 & 99.0 & 6.1 & $6.2 \%$ \\
\hline $3 / 66$ & 102.2 & 96.3 & 5.9 & $6.1 \%$ \\
\hline $4 / 66$ & 99.2 & 93.8 & 5.4 & $5.8 \%$ \\
\hline $5 / 66$ & 96.4 & 91.4 & 5.0 & $5.5 \%$ \\
\hline $6 / 66$ & 93.8 & 89.2 & 4.6 & $5.2 \%$ \\
\hline $7 / 66$ & 91.3 & 87.1 & 4.3 & $4.9 \%$ \\
\hline $8 / 66$ & 89.0 & 85.1 & 3.9 & $4.6 \%$ \\
\hline $9 / 66$ & 86.8 & 83.3 & 3.5 & $4.2 \%$ \\
\hline $10 / 66$ & 84.8 & 81.6 & 3.3 & $4.0 \%$ \\
\hline $11 / 66$ & 82.9 & 80.0 & 3.0 & $3.7 \%$ \\
\hline $12 / 66$ & 81.2 & 78.4 & 2.7 & $3.5 \%$ \\
\hline $1 / 67$ & 79.5 & 77.0 & 2.5 & $3.2 \%$ \\
\hline $2 / 67$ & 77.9 & 75.6 & 2.2 & $3.0 \%$ \\
\hline $3 / 67$ & 46.7 & 47.3 & -0.6 & $-1.3 \%$ \\
\hline $4 / 67$ & 45.8 & 46.5 & -0.6 & $-1.4 \%$ \\
\hline $5 / 67$ & 45.0 & 45.7 & -0.6 & $-1.4 \%$ \\
\hline $6 / 67$ & 44.3 & 44.9 & -0.6 & $-1.4 \%$ \\
\hline $7 / 67$ & 43.6 & 44.2 & -0.6 & $-1.4 \%$ \\
\hline $8 / 67$ & 42.9 & 43.5 & -0.6 & $-1.4 \%$ \\
\hline $9 / 67$ & 42.3 & 42.9 & -0.6 & $.1 .4 \%$ \\
\hline $10 / 67$ & 41.7 & 42.3 & -0.6 & $-1.4 \%$ \\
\hline $11 / 67$ & 41.1 & 41.7 & -0.6 & $-1.4 \%$ \\
\hline $12 / 67$ & 40.6 & 41.1 & -0.5 & $-1.3 \%$ \\
\hline $1 / 68$ & 40.1 & 40.6 & -0.5 & $-1.3 \%$ \\
\hline $2 / 68$ & 39.6 & 40.1 & -0.5 & $-1.3 \%$ \\
\hline $3 / 68$ & 39.2 & 39.7 & -0.5 & $-1.1 \%$ \\
\hline
\end{tabular}


HNF-4756, Rev. 0

This page intentionally left blank.

A-22

$+4$ 


\section{DISTRIBUTION SHEET}

To

DISTRIBUTION

Project Title/Work Order

Assessment of Historical Leak Model Methodology as Applied to the REDOX High-Level Waste Tank SX-108

\begin{tabular}{|c|c|c|c|c|c|}
\hline Name & MSIN & $\begin{array}{l}\text { Text } \\
\text { With All } \\
\text { Attach. }\end{array}$ & Text Only & $\begin{array}{c}\text { Attach./ } \\
\text { Appendix } \\
\text { Only }\end{array}$ & $\begin{array}{c}\text { EDT/ECN } \\
\text { Only }\end{array}$ \\
\hline Central Files & $\mathrm{B} 1-07$ & $\mathrm{x}$ & & & \\
\hline RL Reading Room & H2-53 & $x$ & & & \\
\hline Project File & н $0-22$ & $x$ & & & \\
\hline FJ Anderson & Н0-22 & $\mathrm{x}$ & & & \\
\hline CR Abraham & A1-80 & $\mathrm{x}$ & & & \\
\hline DA Barnes & $\mathrm{R} 2-12$ & $\mathrm{x}$ & & & \\
\hline JF Bertsch & $\mathrm{B} 1-42$ & $x$ & & & \\
\hline HL Boston & H6-64 & $x$ & & & \\
\hline NG Colton & $\mathrm{K} 2-12$ & $\mathrm{x}$ & & & \\
\hline SL Dahl-Crumper & B5-18 & $\mathrm{x}$ & & & \\
\hline JD Davis & Н0-34 & $\mathrm{x}$ & & & \\
\hline KA Gasper & $\mathrm{H} 6-64$ & $x$ & & & \\
\hline CC Haass & $\mathrm{H} 6-64$ & $\mathrm{x}$ & & & \\
\hline MJ Graham & HO-09 & $x$ & & & \\
\hline RD Hilebrand & H0-12 & $x$ & & & \\
\hline RA Holten & HO-12 & $x$ & & & \\
\hline VG Johnson & H6-96 & $\mathrm{x}$ & & & \\
\hline TE Jones & н $0-22$ & $x$ & & & \\
\hline R Khaleel & B4-43 & $\mathrm{x}$ & & & \\
\hline CT Kincaid & $\mathrm{K} 9-33$ & $\mathrm{x}$ & & & \\
\hline AJ Knepp & HO- 22 & $\mathrm{x}$ & & & \\
\hline JL Kovach & H6-61 & $\mathrm{x}$ & & & \\
\hline S Leja & B5-18 & $x$ & & & \\
\hline RW Lober & H6-60 & $\mathrm{x}$ & & & \\
\hline FM Mann & HO-22 & $x$ & & & \\
\hline DA Myers & HO-22 & $x$ & & & \\
\hline DE Olson & $\mathrm{H} 0-12$ & $\mathrm{x}$ & & & \\
\hline JC Peshong & $\mathrm{H} 6-60$ & $x$ & & & \\
\hline JA Poppiti & H6-60 & $x$ & & & \\
\hline VJ Rohay & HO-21 & $\mathrm{x}$ & & & \\
\hline JR Serne & $\mathrm{K} 6-81$ & $\mathrm{x}$ & & & \\
\hline DR Sherwood & B5-01 & $x$ & & & \\
\hline
\end{tabular}

From

RPP Vadose Zone Project

Page 1 of 2

Date 9-21-99

EDT No. 624478

ECN No. 


\section{DISTRIBUTION SHEET}

To

Distribution (Continued)

Project Title/Work Order

Assessment of Historical Leak Model Methodology as Applied to the REDOX High-Level Waste Tank SX-108

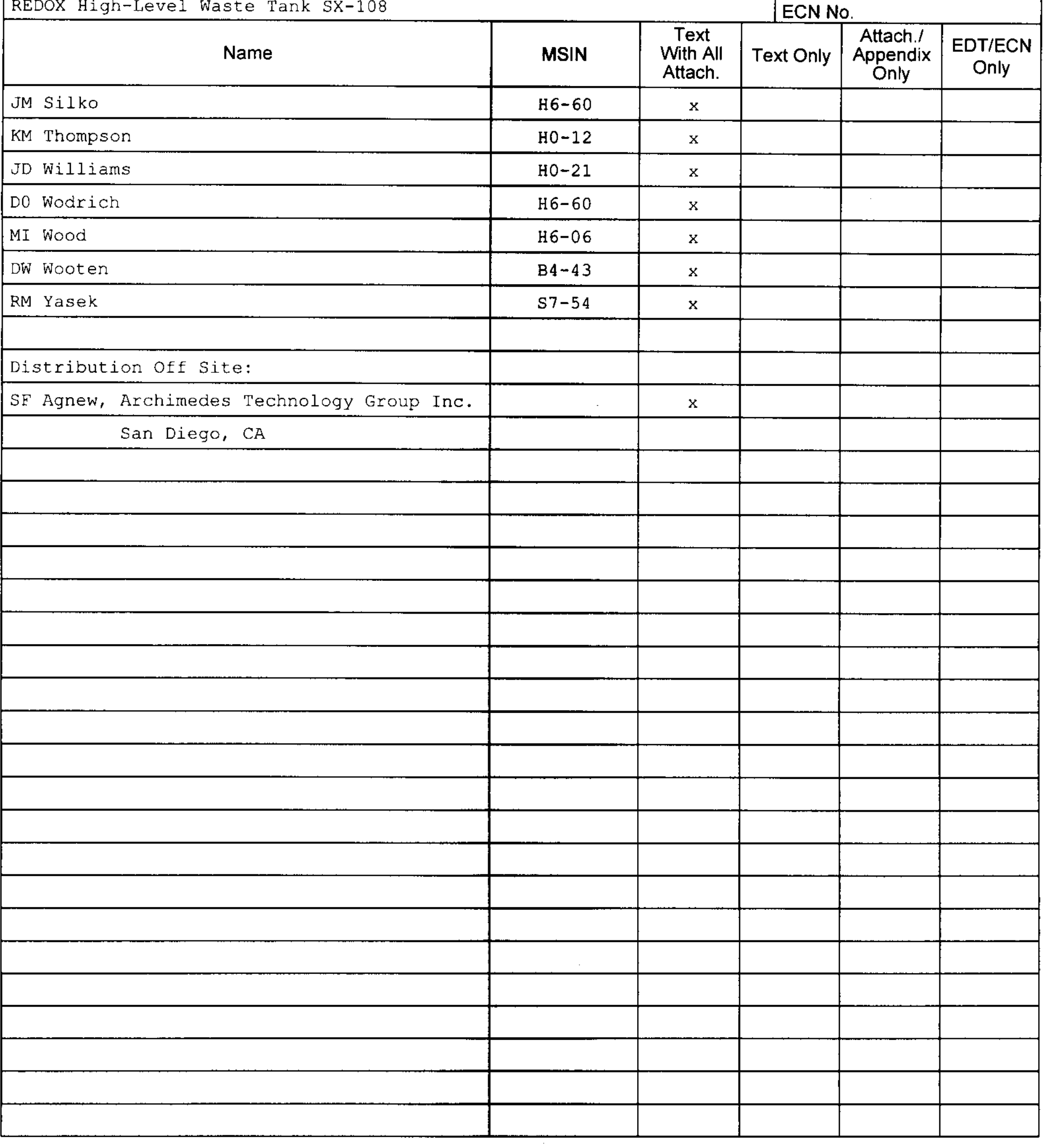

\begin{tabular}{|l|l|}
\hline Page 2 of 2 \\
\hline Date $9 / 21 / 99$ \\
\hline
\end{tabular}

EDT No.

ECN No.

\section{Text}

With All

$\mathrm{x}$

$\mathrm{x}$

$\mathrm{x}$

$\mathrm{x}$

$x$

$x$ 